\title{
Cell-Produced $\alpha$-Synuclein Is Secreted in a Calcium-Dependent Manner by Exosomes and Impacts Neuronal Survival
}

\author{
Evangelia Emmanouilidou, ${ }^{1}$ Katerina Melachroinou, ${ }^{1}$ Theodoros Roumeliotis, ${ }^{2}$ Spiros D. Garbis, ${ }^{2}$ Maria Ntzouni, ${ }^{3}$ \\ Lukas H. Margaritis, ${ }^{3}$ Leonidas Stefanis, ${ }^{1,4}$ and Kostas Vekrellis ${ }^{1}$ \\ Divisions of ${ }^{1}$ Basic Neurosciences and ${ }^{2}$ Biotechnology, Biomedical Research Foundation of the Academy of Athens, Athens 11527, Greece, ${ }^{3}$ Department of \\ Cell Biology and Biophysics, Faculty of Biology, University of Athens, Athens 15701, Greece, and ${ }^{4}$ Second Department of Neurology, University of Athens \\ Medical School, Athens 11527, Greece
}

$\alpha$-Synuclein is central in Parkinson's disease pathogenesis. Although initially $\alpha$-synuclein was considered a purely intracellular protein, recent data suggest that it can be detected in the plasma and CSF of humans and in the culture media of neuronal cells. To address a role of secreted $\alpha$-synuclein in neuronal homeostasis, we have generated wild-type $\alpha$-synuclein and $\beta$-galactosidase inducible SH-SY5Y cells. Soluble oligomeric and monomeric species of $\alpha$-synuclein are readily detected in the conditioned media (CM) of these cells at concentrations similar to those observed in human CSF. We have found that, in this model, $\alpha$-synuclein is secreted by externalized vesicles in a calcium-dependent manner. Electron microscopy and liquid chromatography-mass spectrometry proteomic analysis demonstrate that these vesicles have the characteristic hallmarks of exosomes, secreted intraluminar vesicles of multivesicular bodies. Application of CM containing secreted $\alpha$-synuclein causes cell death of recipient neuronal cells, which can be reversed after $\alpha$-synuclein immunodepletion from the CM. High- and low-molecular-weight $\alpha$-synuclein species, isolated from this CM, significantly decrease cell viability. Importantly, treatment of the $\mathrm{CM}$ with oligomer-interfering compounds before application rescues the recipient neuronal cells from the observed toxicity. Our results show for the first time that cell-produced $\alpha$-synuclein is secreted via an exosomal, calcium-dependent mechanism and suggest that $\alpha$-synuclein secretion serves to amplify and propagate Parkinson's diseaserelated pathology.

\section{Introduction}

Genetic and biochemical data indicate that an increase in the levels of expression of the wild-type (WT) $\alpha$-synuclein protein is sufficient to cause neurodegeneration in Parkinson's disease (PD) (Singleton et al., 2003; Chartier-Harlin et al., 2004; Ibáñez et al., 2004). The aberrant function of $\alpha$-synuclein is not understood, although there is evidence that abnormal folding and aggregation may play a role and that the toxic $\alpha$-synuclein species may be oligomeric intermediates (Conway et al., 2000, 2001; Goldberg and Lansbury, 2000; Olanow et al., 2004; Vekrellis et al., 2004). Until recently, $\alpha$-synuclein was considered to exert its pathogenic effects intracellularly. However, El-Agnaf et al. (2003, 2006) showed that $\alpha$-synuclein species can be detected in human plasma and CSF and that it could be secreted into the medium of cultured neuronal cells. In another report, monomeric and oligomeric $\alpha$-synuclein were shown to be secreted from differentiated human neuroblastoma cells and primary cortical neurons

Received Nov. 17, 2009; revised March 16, 2010; accepted March 19, 2010.

This work was supported in part by National Institutes of Health Grant R21 NS0556 (L.S., K.V.) and by a Rapid Response Grant from the Michael J. Fox Foundation (E.E.).

The authors have nothing to disclose.

Correspondence should be addressed to Kostas Vekrellis, Division of Basic Neurosciences, Biomedical Research Foundation of the Academy of Athens, 4, Soranou Efessiou Street, Athens 11527, Greece. E-mail: vekrellis@ bioacademy.gr.

DOI:10.1523/JNEUROSCI.5699-09.2010

Copyright $\odot 2010$ the authors $\quad 0270-6474 / 10 / 306838-14 \$ 15.00 / 0$
(Lee et al., 2005). Using a similar model, Sung et al. (2005) demonstrated that secreted $\alpha$-synuclein from SK-N-BE cells reduces the viability of these cells and can be cleaved by matrix metalloproteases. These results suggest that the pathogenic actions of $\alpha$-synuclein extend to the extracellular space and neighboring cells. In support for this hypothesis, exogenously added recombinant $\alpha$-synuclein to cell culture medium can be internalized by the recipient cells (Sung et al., 2001; Ahn et al., 2006; Lee et al., 2008; Luk et al., 2009) and cause cell death (Du et al., 2003; Albani et al., 2004; Zhang et al., 2005). Such studies have used very high concentrations of recombinant $\alpha$-synuclein and cationic liposomes to assist its uptake.

The pathophysiological role of the secreted $\alpha$-synuclein forms remains essentially unknown. In one study (Zhang et al., 2005), it was demonstrated that the interaction between recombinant $\alpha$-synuclein and microglia could activate these cells, which in turn induces neurotoxicity. It has also been suggested that $\alpha$-synuclein aggregates can transmit pathology via neuron-toneuron interactions (Desplats et al., 2009). The secretion of $\alpha$-synuclein has been reported to be insensitive to brefeldin A (BFA) (Lee et al., 2005), suggesting that it is secreted via an endoplasmic reticulum (ER)/Golgi-independent, pathway. Electron microscopy and density gradient ultracentrifugation suggested that the vesicles containing $\alpha$-synuclein have morphologies and sedimentation properties similar to the dense core vesicles (Lee et al., 2005), but their exact identities remain unknown. To investigate 
the underlying mechanisms of neurotoxicity caused by cell-secreted $\alpha$-synuclein species, we have generated WT $\alpha$-synuclein-Tet-off inducible SH-SY5Y cells. We show that $\alpha$-synuclein is associated with externalized membrane vesicles, suggestive of a vesiclebased exporting mechanism. Our results show that different species of naturally secreted $\alpha$-synuclein cause cell death to neuronal cells. Immunodepletion of $\alpha$-synuclein from the medium rescues this death. Finally, we demonstrate that treatment of the conditioned medium (CM) with oligomer-disrupting compounds reduces the secreted $\alpha$-synuclein-related cytotoxicity.

\section{Materials and Methods}

Reagents. All reagents were obtained from Sigma unless otherwise specified. Doxycycline (Dox) was purchased from Clontech. Recombinant $\alpha$-synuclein was from Millipore Bioscience Research Reagents. Cytochalasin D (CytoD) and protein G agarose beads were purchased from Calbiochem.

Cell culture. The generation of the stable SH-SY5Y cell lines inducibly expressing WT $\alpha$-synuclein was described previously (Vekrellis et al., 2009). SH-SY5Y cells were cultured in RPMI 1640 medium containing $10 \% \mathrm{FBS}$, penicillin $(100 \mathrm{U} / \mathrm{ml})$, streptomycin $(100 \mu \mathrm{g} / \mathrm{ml})$, and $2 \mathrm{~mm}$ L-glutamine. Cells overexpressing either WT $\alpha$-synuclein or $\beta$-galactosidase (bGAL) were cultured in the presence of $250 \mu \mathrm{g} / \mathrm{ml} \mathrm{G} 418$ and 50 $\mu \mathrm{g} / \mathrm{ml}$ hygromycin B. $\alpha$-Synuclein expression was switched off by the addition of doxycycline $(0.5 \mu \mathrm{g} / \mathrm{ml})$. Stock cultures were kept in the presence of doxycycline. Neuronal differentiation was performed with the addition of $10 \mu \mathrm{m}$ all-trans retinoic acid for $5 \mathrm{~d}$. Cultures of rat (embryonic day 18) cortical neurons were prepared as described previously (Vogiatzi et al., 2008). Dissociated cells were plated onto poly-Dlysine-coated 12-well dishes at a density of $\sim 250.000 / \mathrm{cm}^{2}$. Cells were maintained in Neurobasal medium (Invitrogen), with B27 serum-free supplements (Invitrogen), $0.5 \mathrm{~mm}$ L-glutamine, and penicillin/streptomycin (as above). More than $98 \%$ of the cells cultured under these conditions represent postmitotic neurons (Rideout et al., 2001). Mouse BV2 microglia cells were cultured in RPMI 1640 medium containing 10\% FBS, penicillin $(100 \mathrm{U} / \mathrm{ml})$, streptomycin $(100 \mu \mathrm{g} / \mathrm{ml})$, and $2 \mathrm{~mm}$ L-glutamine.

Preparation of conditioned medium and cell extract. SH-SY5Y cells inducibly expressing WT $\alpha$-synuclein were cultured in 140-mm-diameter dishes in RPMI 1640 medium containing 10\% FBS in the presence or absence of doxycycline $(0.5 \mu \mathrm{g} / \mathrm{ml})$ until $70-80 \%$ confluent. The medium was then replaced with RPMI 1640 medium containing $2 \%$ FBS. After $48 \mathrm{~h}$, the culture supernatant (CM) was collected and centrifuged at $4000 \times g$ for $10 \mathrm{~min}$ at $4^{\circ} \mathrm{C}$ to remove cell debris. For Western blotting and size exclusion chromatography (SEC), the CM was concentrated using $3 \mathrm{kDa}$ cutoff Amicon Ultra filters (Millipore). For toxicity assays, the $\mathrm{CM}$ was used without concentration. In some cases, $\mathrm{CM}$ was treated with $0.4 \mu \mathrm{M}$ of either Congo Red (CR) or scyllo-inositol (SI) for $4 \mathrm{~h}$ at $4^{\circ} \mathrm{C}$ before its addition to recipient cells.

For extraction of cellular proteins, cells were harvested, washed twice with ice-cold PBS, and lysed with STEN lysis buffer (50 mM Tris, pH 7.6, $150 \mathrm{~mm} \mathrm{NaCl}, 0.1 \%$ SDS, $1 \% \mathrm{NP}-40$, and $2 \mathrm{~mm}$ EDTA) on ice for $15 \mathrm{~min}$. Protein content was estimated using the Bradford method (Bio-Rad).

Isolation of externalized membrane vesicles. The isolation of the externalized membrane vesicles was performed as described previously (Tanudji et al., 2002). Briefly, the CM was first centrifuged at $4000 \times g$ for $10 \mathrm{~min}$ at $4^{\circ} \mathrm{C}$ to remove dead cells and debris, and the supernatant was further centrifuged at $100,000 \times g$ for $2 \mathrm{~h}$ at $4^{\circ} \mathrm{C}$. The supernatant $(\mathrm{S} 100)$ was collected, and the pellet (P100) containing the externalized vesicles was reconstituted in $25 \mu \mathrm{l}$ of radioimmunoprecipitation assay (RIPA) buffer (50 mm Tris-HCl, pH 7.6, $150 \mathrm{~mm} \mathrm{NaCl}, 1 \% \mathrm{NP}-40,0.5 \% \mathrm{Na}-$ deoxycholate, and $0.1 \%$ SDS).

Preparation of exosome-depleted medium. The depletion of the medium from bovine serum-derived exosomes was performed as described previously (Théry et al., 2006). Briefly, RPMI 1640 medium containing $20 \%$ FBS, penicillin/streptomycin, and L-glutamine was centrifuged at $100,000 \times g$ for $16 \mathrm{~h}$ at $4^{\circ} \mathrm{C}$. The supernatant was carefully removed and sterilized by filtering through a $0.2 \mu \mathrm{m}$ filter (Whatman) and stored at $4^{\circ} \mathrm{C}$ until additional use in exosome preparation.

Purification of exosomes. Exosomes were prepared as described previously (Théry et al., 2006). Briefly, SH-SY5Y cells were cultured in two 140 $\mathrm{mm}$ dishes in 10\% FBS. At $48 \mathrm{~h}$ before the exosome preparation, culture medium was replaced with exosome-depleted medium diluted 10-fold with RPMI 1640 medium containing only penicillin/streptomycin and L-glutamine. Culture supernatants of cells grown for $48 \mathrm{~h}$ were collected and spun at $300 \times g$ for $10 \mathrm{~min}$ to remove cells. The supernatants were then sequentially centrifuged at $2000 \times g$ for $10 \mathrm{~min}, 10,000 \times g$ for 30 $\mathrm{min}$, and $100,000 \times g$ for $90 \mathrm{~min}$. The pellet (P100) containing exosomes was washed once with cold PBS and centrifuged again at $100,000 \times g$ for 90 min. P100 was resuspended in $50 \mu \mathrm{l}$ of RIPA buffer. All centrifugations were performed at $4^{\circ} \mathrm{C}$.

Electron microscopy. Externalized membrane vesicles were isolated from $15 \mathrm{ml}$ of CM, and electron microscopy was performed as described previously (Théry et al., 2006) with some modifications. Briefly, vesicles were fixed with $2 \%$ paraformaldehyde in $100 \mathrm{~mm} \mathrm{Na}_{2} \mathrm{HPO}_{4}$, applied to a Formvar-coated copper grid, and negatively stained with $2 \%$ uranyl acetate. Microphotographs were obtained using a Phillips EM 300 electron microscope.

Mass spectrometric protein analyses. The proteins were extracted from the exosomes using an acetone-TCA precipitation procedure followed by washes with acetonitrile and tetrahydrofuran. The resulting protein pellets were subjected to reduction, alkylation, and in-solution phase proteolysis with trypsin as described previously (Kouri et al., 2009). The resulting tryptic digest was analyzed with an Agilent 1200 nano-liquid chromatography system interfaced with an Agilent 6330 MSD ion trap mass spectrometer system retrofitted to a nanoelectrospray ionization source [liquid chromatography-mass spectrometry (LC-MS)]. The capillary column used for the peptide separation was the Agilent $\mathrm{C}_{18}$ Zorbax at $1.8 \mu \mathrm{m}$ particle size, $75 \mu \mathrm{m}$ inner diameter, and $150 \mathrm{~mm}$ length. Before the analyses, the LC-MS system was tuned and calibrated to meet the specifications of the manufacturer for mass accuracy and detection sensitivity. The obtained product ion $\mathrm{MS}^{2}$ peptide spectra were searched against the Swiss Prot nonredundant sequence database. The search engine used was Protein Pilot (version 2.0.1) with the ESI-Trap instrument option, Search Effort at Thorough ID, and a detection protein threshold $>1.3$ ( $>95 \%$ confidence).

Treatment of vesicles with $\mathrm{Na}_{2} \mathrm{CO}_{3}$. To remove non-integral membrane proteins, exosomes were treated with $\mathrm{Na}_{2} \mathrm{CO}_{3} 100 \mathrm{~mm}$, $\mathrm{pH} 11$, for $30 \mathrm{~min}$ at $4^{\circ} \mathrm{C}$ (Fujiki et al., 1982). After centrifugation at 50,000 $\times \mathrm{g}$, integral exosomal membrane proteins were recovered in the pellet fraction, whereas the exosomal lumen proteins remained in the soluble fraction.

${ }^{35} \mathrm{~S}$ radiolabeling. SH-SY5Y cells inducibly expressing WT $\alpha$-synuclein were cultured in 140-mm-diameter dishes in RPMI 1640 medium containing 10\% FBS in the presence or absence of Dox until $70-80 \%$ confluent. Cells were starved from methionine and cysteine for 15 $\mathrm{min}$ at $37^{\circ} \mathrm{C}$. After starvation, $2.5 \mathrm{mCi}$ of ${ }^{35} \mathrm{~S}$-Protein Labeling mix (PerkinElmer Life and Analytical Sciences) were added for $3 \mathrm{~h}$. Cells were rinsed twice with plain RPMI 1640 medium and grown overnight in fresh unlabeled culture medium with excess of L-methionine and $\mathrm{L}$-cysteine (10 $\mathrm{mm}$ final concentration). The $\mathrm{CM}$, containing radiolabeled secreted proteins, was collected, cleared from cell debris, concentrated, and analyzed by immunoblotting. To detect intracellular radiolabeled proteins, cells were first washed for 2 min with trypsinEDTA to remove non-integral membrane-bound proteins. After centrifugation at $400 \times g$ for $5 \mathrm{~min}$, cell pellets were lysed in STEN lysis buffer and used for immunoprecipitation.

Immunoprecipitation of labeled $\alpha$-synuclein. Cell lysates were precleared with protein-G agarose beads for $1 \mathrm{~h}$ at $4^{\circ} \mathrm{C}$. Agarose beads were removed by centrifugation at $1000 \times g$ for $5 \mathrm{~min}$ at $4^{\circ} \mathrm{C}$, and anti- $\alpha$ synuclein antibody (Syn-1, mouse monoclonal, $5 \mu \mathrm{g} / \mathrm{mg}$ protein; BD Biosciences) was added for $6 \mathrm{~h}$ at $4^{\circ} \mathrm{C}$ by rotation. At the end of this period, protein- $\mathrm{G}$ agarose beads were added and the mixture was incubated overnight at $4^{\circ} \mathrm{C}$ by rotation. Labeled $\alpha$-synuclein was detected by gel autoradiography.

Immunodepletion of CM. Conditioned medium (7 ml) was immunodepleted of $\alpha$-synuclein by immunoprecipitation with anti- $\alpha$-synuclein anti- 
body $(0.5 \mu \mathrm{g} / \mathrm{ml} \mathrm{CM})$ as described above. Immunodepleted CM was collected and sterilized by filtering through a $0.2 \mu \mathrm{m}$ filter (Whatman) before being applied on recipient cells. Control immunodepletion was performed with either anti-c-myc antibody (mouse monoclonal; Santa Cruz Biotechnology) or protein-G agarose alone.

Uptake of radiolabeled proteins. Cells were treated overnight with $\mathrm{CM}$ containing radiolabeled secreted proteins (see above). After 2 min treatment with trypsin-EDTA to remove nonspecific surface protein binding, cells were examined for the internalization of labeled $\alpha$-synuclein by immunoprecipitation and gel autoradiography.

Subcellular fractionation. After overnight application of CM containing ${ }^{35}$ S-labeled secreted proteins, recipient cells were treated with trypsin-EDTA, washed once with PBS, and centrifuged at $400 \times g$ for 5 min at $4^{\circ} \mathrm{C}$. Cell pellet was resuspended in a detergent-free buffer containing $0.25 \mathrm{~m}$ sucrose, $10 \mathrm{~mm}$ HEPES, pH 7.4, $1 \mathrm{~mm}$ EDTA, $5 \mathrm{~mm} \mathrm{MgCl}_{2}$, and $1 \times$ cocktail protease inhibitors (Roche). Homogenization was achieved first by four freeze-thaw cycles, followed by three sets of 15 bounces of a Teflon homogenizer. Finally, the homogenate was passed a few times through an insulin syringe. For nuclei sedimentation, the homogenate was centrifuged at $2000 \times g$ for $15 \mathrm{~min}$ at $4^{\circ} \mathrm{C}$. To isolate microsomes, the supernatant was further centrifuged at $100,000 \times g$ for $2 \mathrm{~h}$ at $4^{\circ} \mathrm{C}$. Pellets were washed twice with PBS containing protease inhibitors and reconstituted in RIPA buffer. Nuclear, microsomal, and cytosolic fractions were finally analyzed for the presence of internalized $\alpha$-synuclein by immunoprecipitation and autoradiography.

Toxicity assays. Toxicity was assessed by using the LIVE/DEAD viability/cytotoxicity kit (Invitrogen). Briefly, cells were stained by $2 \mu \mathrm{M}$ calcein-AM, which labels living cells, and $1 \mu \mathrm{M}$ ethidium homodimer (EthD-1), which labels dead cells, for $30 \mathrm{~min}$. Hoechst 33258 dye was used at the same time for total nuclei staining. After staining, cells were washed once with normal RPMI 1640 medium and immediately visualized on a Leica DMIRB inverted fluorescence microscope. Images were captured under $20 \times$ magnification with a Leica DFC-350FX digital cooled CCD camera using the LAS AF software. Toxicity was defined in each image as the percentage of dead cells versus the total number of cells, counting at least 150 cells per image.

Size exclusion chromatography. For SEC, 8-9 mg of protein of concentrated CM diluted in PBS were injected into a Superdex 200 10/300 GL column (GE Healthcare) previously equilibrated with PBS. Elution was performed at a constant flow rate of $0.25 \mathrm{ml} / \mathrm{min}$ in PBS. The $250 \mu \mathrm{l}$ fractions were collected and analyzed by Western immunoblotting for the presence of $\alpha$-synuclein. High-molecular-weight (HMW) and lowmolecular-weight (LMW) fractions containing $\alpha$-synuclein were separately pooled and concentrated using $3 \mathrm{kDa}$ cutoff filters (Millipore). PBS was exchanged to $50 \mathrm{~mm}$ ammonium acetate buffer, $\mathrm{pH} 7.5$, by means of ultrafiltration, and the samples were further lyophilized to dryness. Finally, samples were reconstituted in $250 \mu$ of RPMI 1640 medium containing 10\% FBS, sterilized by filtering, and applied to recipient cells in $2 \times$ concentration.

Western immunoblotting. Denaturing gel electrophoresis was performed in 12\% SDS-PAGE gels in Tris-glycine buffer. Immunoblotting was performed using the following antibodies: anti- $\alpha$-synuclein (rabbit polyclonal from Santa Cruz Biotechnology; C-20 or Syn-1 monoclonal from BD Biosciences), anti- $\beta$-actin (mouse monoclonal; Sigma), anti- $\gamma$ tubulin (mouse monoclonal; Sigma), anti-BSA (mouse monoclonal; Antibody Shop), anti-Alix (mouse monoclonal; Santa Cruz Biotechnology), anti-heat shock protein 70 (Hsp70) (mouse monoclonal; Stressgen), anti-glyceraldehyde-3-phosphate dehydrogenase (GAPDH) (mouse monoclonal; Sigma), anti-14-3-3 $\beta$ (rabbit polyclonal; Santa Cruz Biotechnology), anti-extracellular signal-regulated kinase (ERK) (rabbit polyclonal; Santa Cruz Biotechnology), anti-ubiquitin (mouse monoclonal; Millipore Bioscience Research Reagents), anti-cofilin (goat polyclonal; Santa Cruz Biotechnology), anti-flotillin-1 (mouse monoclonal; Santa Cruz Biotechnology), anti-annexin II (rabbit polyclonal; Santa Cruz Biotechnology), anti-c-myc (mouse monoclonal; Sigma), anticleaved caspase-3 (rabbit monoclonal; Cell Signaling Technology), and anti-19S Rpt6 proteasome subunit (mouse monoclonal; Biomol). All immunoblots represent one of at least three experiments. Quantification of bands on Western immunoblots was performed using Gel Analyser software (Biosure). Differences in protein expression levels were quantified after standardization of all values using the appropriate loading controls ( $\gamma$-tubulin, $\beta$-actin, ERK, and BSA). All statistical analyses were performed using the Student's $t$ test, and $p$ values of $<0.05$ were considered significant.

Immunocytochemistry and confocal microscopy. For confocal microscopy, cells grown on glass coverslips were fixed with $4 \%$ paraformaldehyde for $15 \mathrm{~min}$. After PBS washes, cells were blocked with $10 \%$ normal goat serum (NGS) in PBS. Primary anti-GM130 antibody (mouse monoclonal, 1:100; BD Biosciences Transduction Laboratories) was applied for $16 \mathrm{~h}$ in PBS containing 2\% NGS and $0.1 \%$ Triton X-100. Mouse cyanine 3 (Cy3) secondary antibody (Jackson ImmunoResearch) was added for $1 \mathrm{~h}$ in PBS/Triton X-100/NGS. Alternatively, cells were stained for $16 \mathrm{~h}$ with Alexa 633-phalloidin (1:500; Invitrogen). Cell nuclei were stained with Hoechst 33258 dye. Coverslips were mounted in Mowiol mounting media and visualized under $63 \times$ magnification using a Leica TCS SP5 confocal microscope combined with dual (tandem) scanner.

\section{Results}

\section{$\alpha$-Synuclein is constitutively and physiologically secreted}

In our SH-SY5Y cell system, the expression of WT $\alpha$-synuclein is tightly regulated through the Tet-off regulatory system (Vekrellis et al., 2009). To investigate whether $\alpha$-synuclein is released from our cells, we induced $\alpha$-synuclein expression by culturing cells in the absence of Dox for $8 \mathrm{~d}$ and examined the culture medium (CM) for the presence of secreted $\alpha$-synuclein (Fig. 1A). CM was concentrated and Western immunoblotted with Syn-1 antibody. Secreted monomeric (Fig. 1A) and oligomeric (Fig. 1B) $\alpha$-synuclein was clearly detected in the CM and accumulated over time (Fig. $1 A$, right). This was suggestive of $\alpha$-synuclein being secreted by SH-SY5Y cells in a constitutive manner (Fig. 1C). We confirmed that the presence of $\alpha$-synuclein in the CM was not attributable to cell death by measuring the percentage cell death before CM collection. Using the LIVE/DEAD Cytotoxicity kit, cell death was $<5 \%$ in cells expressing or not expressing $\alpha$-synuclein (percentage cell death, $4.1 \pm 0.9$ or $3.8 \pm 0.3 \%$ for WT-positive and WT-negative cells, respectively, mean $\pm \mathrm{SD}$; $n=3$ ). We further confirmed the physiologic secretion of $\alpha$-synuclein by analyzing the CM for the presence of cytosolic proteins, such as ubiquitin (Fig. $1 A)$, protein kinase $\mathrm{C} \alpha(\mathrm{PKC} \alpha)$, and 19S Rpt6 proteasome subunit (supplemental Fig. S1 A, available at www.jneurosci.org as supplemental material). Both polyubiquitinated proteins and monomeric ubiquitin were absent in the CM of SH-SY5Y cells (Fig. 1A). We also examined the CM from SH-SY5Y cells overexpressing bGAL in a similar manner. No bGAL was detected in the CM of these cells (data not shown), arguing that overexpression alone was not sufficient to lead to $\alpha$-synuclein release. In agreement with a physiological mode of release, secreted $\alpha$-synuclein was detected in low levels in control (+Dox) SH-SY5Y cells (see Figs. $1 B, 3 A, B$ ) (supplemental Figs. $\mathrm{S} 1 A$, available at www.jneurosci.org as supplemental material). We also quantified the levels of $\alpha$-synuclein in the CM after $48 \mathrm{~h}$ using recombinant $\alpha$-synuclein as standard. The concentration of secreted $\alpha$-synuclein was estimated to be $2-12 \mathrm{nM}$, which resembles the levels so far detected in biological fluids (data not shown) (Borghi et al., 2000; El-Agnaf et al., 2003, 2006).

Having shown that our cells physiologically secrete $\alpha$-synuclein, we went on to investigate the manner of this secretion. It has been suggested previously that $\alpha$-synuclein exocytosis is mediated by a nonclassical, BFA-independent, secretory mechanism (Lee et al., 2005). Treatment of SH-SY5Y cells with 2 $\mu \mathrm{g} / \mathrm{ml} \mathrm{BFA}$, an effective inhibitor of the classical ER/Golgidependent pathway, for $6 \mathrm{~h}$ resulted in a robust disassembly of the Golgi complex (supplemental Fig. S1B, available at 

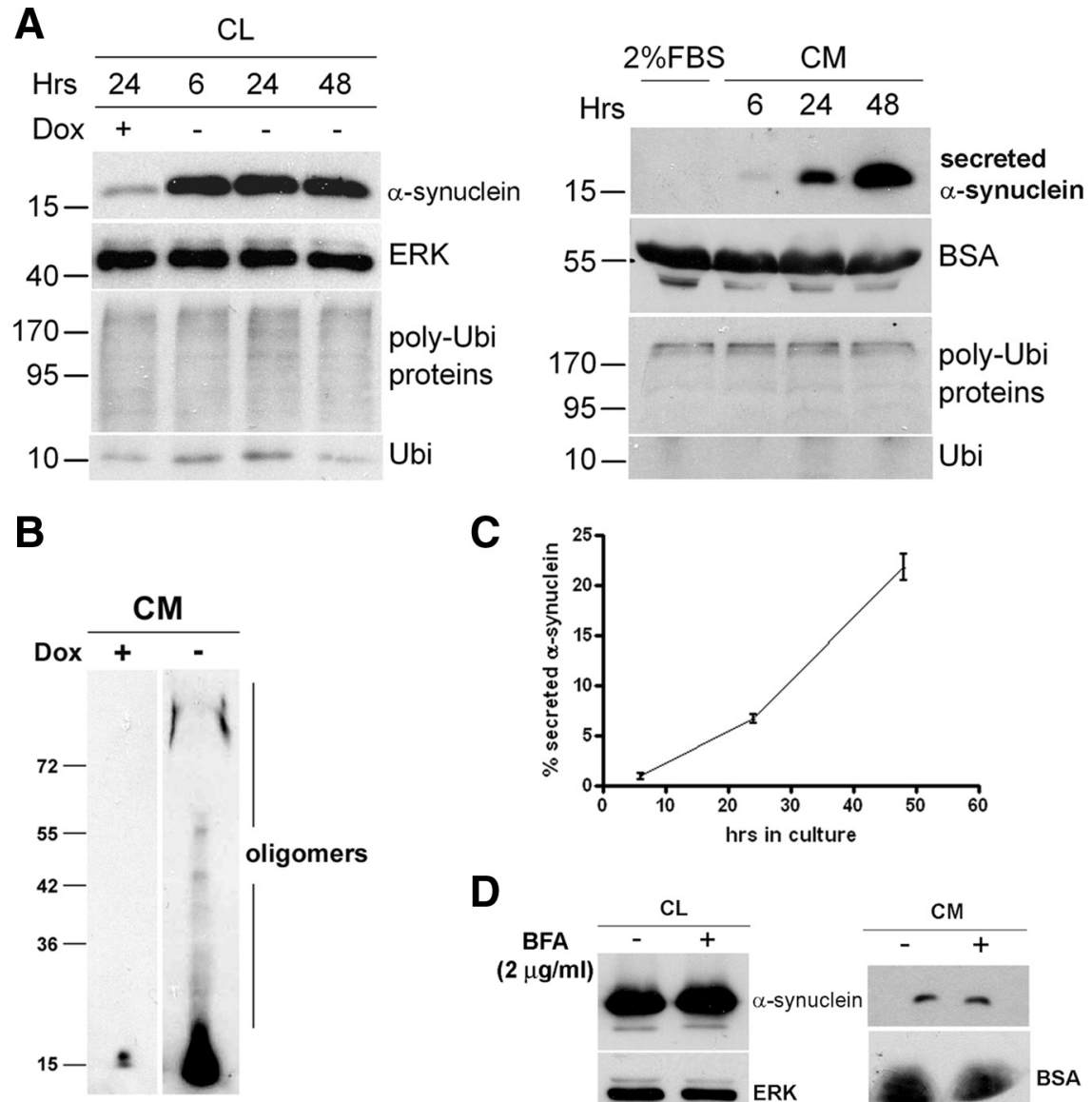

C

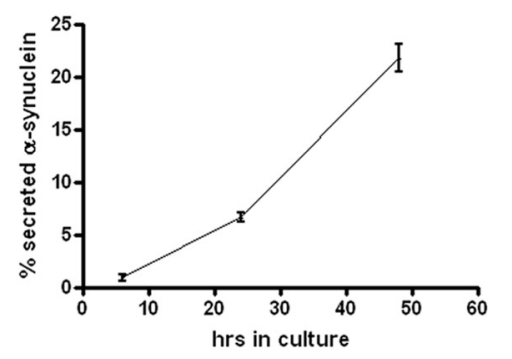

D

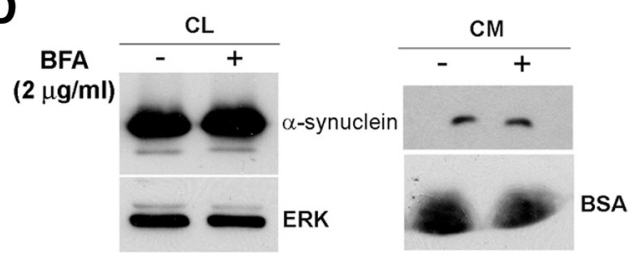

Figure 1. $\alpha$-Synuclein is constitutively released by a nonclassical secretory pathway. $\mathbf{A}, \mathrm{SH}-\mathrm{SY} 5 \mathrm{Y}$ cells were cultured in the presence or absence of Dox for $8 \mathrm{~d}$ in $10 \% \mathrm{FBS}$. After that period, the culture medium was replaced with $2 \% \mathrm{FBS}$ medium for the indicated times. Cell lysates (CL; left) and concentrated CM (right) were analyzed by Western immunoblotting with antibodies to $\alpha$-synuclein or ubiquitin (Ubi). ERK and BSA levels were used as loading controls. B, SH-SY5Y cells were cultured as in $A$, and the CM was collected after $48 \mathrm{~h}$ and analyzed by Western immunoblotting with $\mathrm{C}-20$ antibody. $C$, Representative plot showing the levels of secreted $\alpha$-synuclein, estimated as the percentage ratio of the extracellular $\alpha$-synuclein versus the intracellular $\alpha$-synuclein, over time. Each point represents the mean $\pm S D$ of three measurements. $\boldsymbol{D}, \alpha$-Synuclein-expressing cells were treated with 2 $\mu \mathrm{g} / \mathrm{ml} \mathrm{BFA} \mathrm{(+)} \mathrm{or} \mathrm{without} \mathrm{(-)} \mathrm{for} 6 \mathrm{~h}$. The levels of intracellular $\alpha$-synuclein (CL) and extracellular $\alpha$-synuclein (CM) were assessed by Western immunoblotting. ERK and BSA were used as loading controls.

www.jneurosci.org as supplemental material). BFA-induced disruption of the classical secretory pathway did not alter the levels of secreted $\alpha$-synuclein (percentage secreted $\alpha$-synuclein, $3.5 \pm 0.3$ and $2.1 \pm 1.1 \%$ for CTL untreated and BFA-treated cells, respectively, mean $\pm \mathrm{SD} ; n=3$ ), suggesting that $\alpha$-synuclein indeed follows an unconventional secretory pathway (Figs. 1D, $2 B$ ).

\section{Externalization of $\alpha$-synuclein is sensitive to changes in temperature \\ and serum content}

Facilitated protein secretion, such as classical ER/Golgi transport, is generally a temperature-dependent process (Saraste et al., 1986). However, passive diffusion through a pore in the cell membrane is not affected by changes in temperature (Melchior and Gerace, 1995). In addition, heat shock conditions can induce the release of some proteins exported via leaderless secretory pathways (Rubartelli et al., 1990; Jackson et al., 1992; Lindstedt et al., 1993). The effect of heat shock on $\alpha$-synuclein export was tested by culturing $\alpha$-synuclein-expressing cells at $40^{\circ} \mathrm{C}$ for $6 \mathrm{~h}$. Under these conditions, an upregulation of
Hsp70 was observed (supplemental Fig. S1C, top, available at www.jneurosci. org as supplemental material), whereas cell viability remained unchanged (data not shown). CM from CTL and heat-shocked cells was concentrated and subjected to SDS-PAGE and immunoblotting analysis for the presence of secreted $\alpha$-synuclein. The release of $\alpha$-synuclein was greatly increased under heat shock conditions (percentage secreted $\alpha$-synuclein, $3.4 \pm$ 0.4 and $11.6 \pm 3.0 \%$ for CTL and heatshocked cells, respectively, mean $\pm \mathrm{SD}$; $n=3$ ) (supplemental Fig. S1C, top, available at www.jneurosci.org as supplemental material) but not in lower temperatures such as $25^{\circ} \mathrm{C}$ (supplemental Fig. S1C, bottom, available at www. jneurosci.org as supplemental material). These results suggest that the externalization of $\alpha$-synuclein does not occur through passive diffusion across the plasma membrane.

It has been reported that unconventional protein secretion is affected by factors present in serum (Chang et al., 1997; Tanudji et al., 2002). To examine this possibility, $\alpha$-synuclein-expressing cells were cultured in medium containing 0,2, and 5\% FBS for $6 \mathrm{~h}$. Quantification of cell death verified that, under these conditions, serum deprivation did not affect cell viability (percentage cell death, $2.2 \pm 0.6,2.8 \pm 0.2,2.3 \pm 0.6$, and $3.2 \pm 0.3 \%$ for $0,2,5$, and $10 \%$, respectively, mean $\pm \mathrm{SD} ; n=3$ ). However, the release of $\alpha$-synuclein observed was inversely related to the serum content (percentage secreted $\alpha$-synuclein, $2.8 \pm 0.4$ and $21.7 \pm 1.5 \%$ for 2 and $0 \%$ FBS, respectively, mean $\pm \mathrm{SD} ; n=3$ ) (supplemental Fig. S1D, available at www.jneurosci.org as supplemental material).

\section{$\alpha$-Synuclein is released by a calcium-dependent} endosomal mechanism

To dissect the secretory mechanism of $\alpha$-synuclein in more detail, we tested whether the levels of extracellular $\alpha$-synuclein were altered after treatment with chemical compounds that have been reported previously to influence the nonclassical secretion of other proteins. Because the importance of the actin network on endocytosis/exocytosis and vesicle trafficking has been well established (Lanzetti, 2007), we first investigated the role of actin cytoskeleton on $\alpha$-synuclein secretion. For this purpose, cells expressing $\alpha$-synuclein were treated for $6 \mathrm{~h}$ with $2 \mu \mathrm{M}$ of the actin polymerization inhibitor CytoD (supplemental Fig. S2A, available at www.jneurosci.org as supplemental material). The CM from CTL and CytoD-treated cells were concentrated and analyzed by SDS-PAGE and immunoblotting for secreted $\alpha$-synuclein. Actin depolymerization did not affect $\alpha$-synuclein externalization to a significant extent (percentage secreted $\alpha$-synuclein, $2.5 \pm 1.7$ and $2.9 \pm 1.1 \%$ for CTL and CytoDtreated cells, mean $\pm \mathrm{SD} ; n=3$ ) (Fig. $2 B$ ). Under these conditions, cell viability was not compromised (Fig. $2 C$ ). 
Protein kinases play a prominent role in signal transduction pathways that could facilitate protein trafficking, including unconventional secretion (Seino and Shibasaki, 2005). We have used staurosporin, a nonselective, broad kinase inhibitor (Klinkspoor et al., 1996; Smolian et al., 2001), to test whether protein kinases are involved in the unconventional secretion of $\alpha$-synuclein. $\alpha$-Synuclein-expressing cells were treated for $6 \mathrm{~h}$ with $100 \mathrm{~nm}$ staurosporin, and the CM were collected and concentrated. This treatment inhibited the phosphorylation of p-MARCKS (myristoylated alanine-rich protein kinase $C$ substrate), a specific substrate of $\mathrm{PKC}$, without affecting the levels of the enzyme (supplemental Fig. S2 B, available at www.jneurosci.org as supplemental material). Again, cell viability was not compromised (Fig. 2C). Protein kinase inhibition did not change the levels of extracellular $\alpha$-synuclein (percentage secreted $\alpha$-synuclein, $2.5 \pm 0.8$ and $3.0 \pm$ $1.4 \%$ for CTL and staurosporin-treated cells, mean $\pm \mathrm{SD} ; n=3$ ), indicating that protein kinases do not mediate $\alpha$-synuclein export (Fig. $2 B$ ).

Calcium is fundamental in regulating exocytosis, early endosome fusion, and exosome-mediated release (Mills et al., 2001; Savina et al., 2003; Barclay et al., 2005). To determine whether changes in $\mathrm{Ca}^{2+}$ levels modulate $\alpha$-synuclein secretion, we first treated cells with $0.5 \mathrm{~mm}$ EDTA for $6 \mathrm{~h}$, and the CM were collected and concentrated. Secreted $\alpha$-synuclein levels were assessed by SDS-PAGE and immunoblotting. Removal of extracellular $\mathrm{Ca}^{2+}$ did not change the levels of secreted $\alpha$-synuclein (percentage secreted $\alpha$-synuclein, $3.8 \pm 1.7$ and $3.1 \pm 0.5 \%$ for CTL and EDTA-treated cells, mean $\pm \mathrm{SD} ; n=3$ ) (Fig. $2 A, B$ ). However, when cells were treated with $100 \mathrm{~nm}$ thapsigargin (Thastrup et al., 1990), which raises cytosolic $\mathrm{Ca}^{2+}$ concentration, we observed a significant increase in the levels of secreted $\alpha$-synuclein (percentage secreted $\alpha$-synuclein, $2.6 \pm 0.3$ and $7.7 \pm 2.2 \%$ for CTL and thapsigargin-treated cells, mean $\pm \mathrm{SD} ; n=3$ ) (Fig. $2 A, B)$. This result was confirmed using the calcium ionophore ionomycin. Treatment of $\alpha$-synucleinexpressing cells with $100 \mathrm{~nm}$ ionomycin for $6 \mathrm{~h}$ led to a significant increase in the levels of extracellular $\alpha$-synuclein (percentage secreted $\alpha$-synuclein, $3.1 \pm 0.8$ and $6.6 \pm 0.9 \%$ for CTL and ionomycin-treated cells, mean $\pm \mathrm{SD} ; n=3$ ) (Fig. $2 A, B$ ). As expected, ionomycin treatment also increased the levels of secreted oligomeric $\alpha$-synuclein (supplemental Fig S2C, available at www.jneurosci.org as supplemental material). To further verify that intracellular $\mathrm{Ca}^{2+}$ is important for $\alpha$-synuclein secretion, we used the membrane-permeable $\mathrm{Ca}^{2+}$-chelator BAPTA-AM. Treatment with $2 \mu \mathrm{M}$ BAPTA-AM for $6 \mathrm{~h}$ decreased the levels of secreted $\alpha$-synuclein, further supporting the idea that intracellular $\mathrm{Ca}^{2+}$ acts as a key regulator of $\alpha$-synuclein export (percentage secreted $\alpha$-synuclein, $3.4 \pm 0.4$ and $1.8 \pm 0.5 \%$ for CTL and BAPTA-AM-treated cells, mean $\pm \mathrm{SD} ; n=3$ ) (Fig. $2 A, B$ ). It should be noted that all compounds used for manipulation of $\mathrm{Ca}^{2+}$ concentration did not affect cell viability (Fig. 2C).

We next investigated whether the endocytic pathway is implicated in the process of $\alpha$-synuclein externalization. Weak bases have been shown to prevent endosomal/lysosomal acidification, ultimately resulting in osmotic swelling and vacuolation of lysosomes (Poole and Ohkuma, 1981). We have initially used the lysosomotropic amine methylamine, to impair the lysosomal pathway (Lindstedt et al., 1993; Geetha and Wooten, 2008). We found that blockage of the lysosomal pathway by $2 \mathrm{~mm}$ methylamine caused a profound increase in the levels of secreted $\alpha$-synuclein (percentage secreted $\alpha$-synuclein, $3.4 \pm 0.4$ and $10.8 \pm 2.4 \%$ for CTL and methylamine-treated cells, mean \pm SD; $n=3$ ) (Fig. $2 A, B$ ) without affecting cell viability (Fig. 2C). This indicated that the endocytic pathway could be involved in $\alpha$-synuclein secretion. We verified this finding by using chloroquine (CQ), which potentially perturbs membrane trafficking from endosomes to lysosomes (Andrei et al., 1999; Savina et al., 2003; Yuyama et al., 2008). Treatment with $25 \mu \mathrm{M}$ CQ for $6 \mathrm{~h}$, which resulted in obvious vacuolation (supplemental Fig. S2 D, available at www.jneurosci.org as supplemental material) but not cell death (Fig. $2 C$ ), induced a significant increase in the levels of 
A

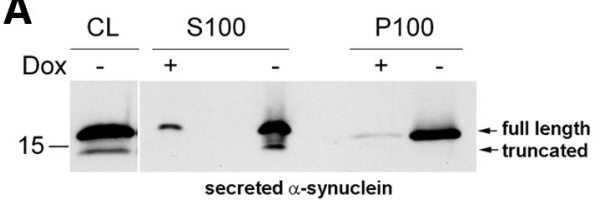

B

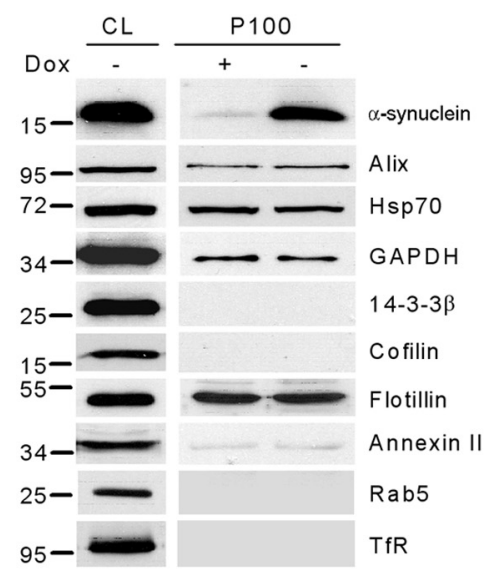

C

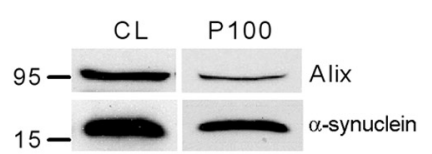

D
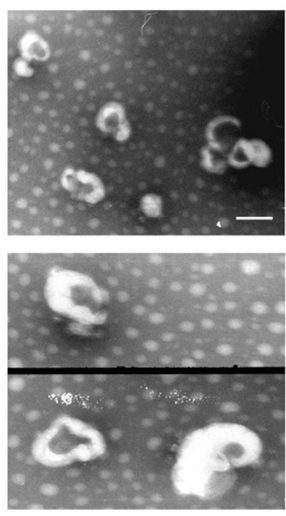

E

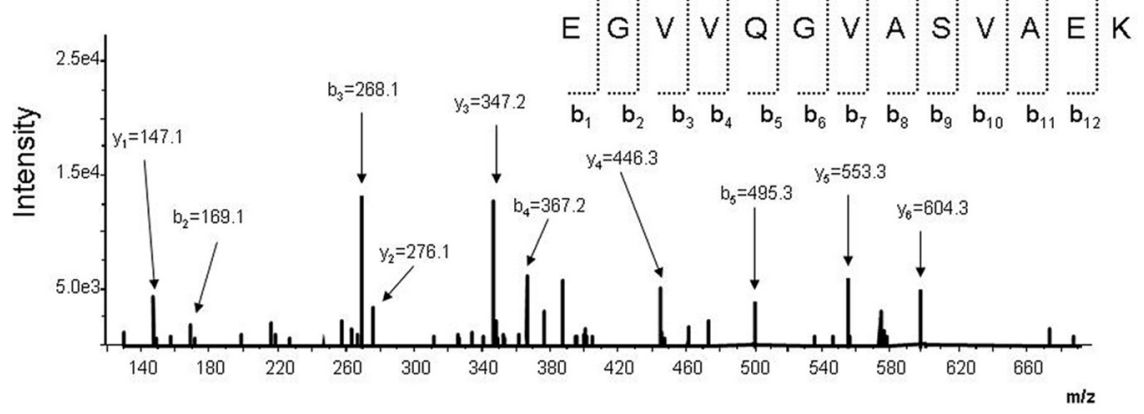

$\mathbf{F}$

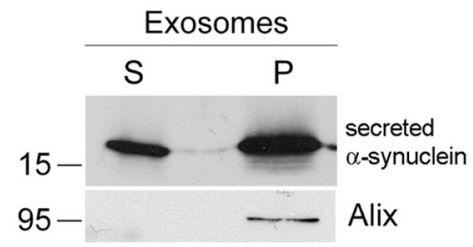

Figure 3. $\alpha$-Synuclein exocytosis is mediated by membrane vesicles that resemble exosomes. $\boldsymbol{A}, \alpha$-Synuclein-expressing cells and nonexpressing CTL cells were cultured in $2 \%$ FBS for $48 \mathrm{~h}$. After ultracentrifugation of the CM, the membrane (P100) and the soluble (S100) fractions were analyzed for $\alpha$-synuclein with the polyclonal C-20 antibody. B, P100 pellets were reconstituted in RIPA buffer and analyzed by Western immunoblotting with antibodies against the proteins indicated. TfR, Transferrin receptor. C, P100 pellet representing pure exosomes was analyzed using antibodies against $\alpha$-synuclein $(C-20)$ and Alix. D, Externalized membrane vesicles were prepared as in $\boldsymbol{A}$. After fixation, vesicles were negatively stained with $2 \%$ uranyl acetate and observed by electron microscopy. Scale bar, $100 \mathrm{~nm}$. $\boldsymbol{E}$, Analysis of externalized membrane vesicles by mass spectrometry. The annotated product ion $\mathrm{MS}^{2}$ spectrum of the tryptic peptide EGVVQGVASVAEK traceable to $\alpha$-synuclein is depicted. $\boldsymbol{F}$, The P100 fraction containing exosomes was treated with $\mathrm{Na}_{2} \mathrm{CO}_{3}$. After a 50,000 $\times g$ centrifugation, the integral membrane proteins were recovered in the pellet (P), whereas non-integral and lumen proteins remained in the supernatant (S). P and S were analyzed for $\alpha$-synuclein by immunoblotting with the $\mathrm{C}-20$ antibody.

secreted $\alpha$-synuclein, although the increase was not as profound as with methylamine (percentage secreted $\alpha$-synuclein, $3.6 \pm 0.5$ and $5.0 \pm 0.5 \%$ for CTL and CQ-treated cells, mean \pm SD; $n=3$ ) (Fig. $2 A, B$ ). We concluded that the endocytic pathway is involved in $\alpha$-synuclein secretion.

\section{Cellular stressors do not lead to alterations of $\alpha$-synuclein secretion}

Oxidative stress has been shown to increase $\alpha$-synuclein levels and apoptosis in a variety of cell models (Sherer et al., 2002). To

examine the effect of oxidative stress on $\alpha$-synuclein secretion, we treated $\alpha$-synuclein-expressing cells with $0.5 \mu \mathrm{M} \mathrm{H}_{2} \mathrm{O}_{2}$ and $\quad 0.25 \mathrm{mM}$ 1-methyl-4-phenylpyridinium $\left(\mathrm{MPP}^{+}\right)$for $6 \mathrm{~h}$ and assessed extracellular $\alpha$-synuclein levels by immunoblotting using the C-20 antibody. Our results suggest that oxidative stress does not affect the levels of secreted $\alpha$-synuclein in our cell system (percentage secreted $\alpha$-synuclein, $2.44 \pm 0.63,3.48 \pm 0.52$, and $2.28 \pm 0.44 \%$ for CTL, $\mathrm{H}_{2} \mathrm{O}_{2}$-treated, and $\mathrm{MPP}^{+}$-treated cells, mean $\pm \mathrm{SD} ; n=3$ ) (Fig. 2D). In another study (Lee et al., 2005), it was demonstrated that proteasome inhibition increases intracellular and extracellular $\alpha$-synuclein aggregates. To address a role of proteasomal function in $\alpha$-synuclein secretion, we treated $\alpha$-synuclein-expressing cells with the potent proteasome inhibitor I (PSI) (10 nM) for $6 \mathrm{~h}$. Immunoblotting of the concentrated $\mathrm{CM}$ with the C-20 antibody revealed that proteasome inhibition did not alter extracellular $\alpha$-synuclein levels (percentage secreted $\alpha$-synuclein, $2.44 \pm 0.63$ and $2.86 \pm 0.46 \%$ for CTL and PSI-treated cells, mean \pm SD; $n=3$ ) (Fig. 2D).

In these studies, we ensured that the levels of the pharmacological stressors used did not lead to cytotoxicity (Fig. 2C), so as to avoid the confounding factor of leakage of $\alpha$-synuclein from dying cells. We cannot therefore exclude the possibility that higher levels of these stressors could impact, in addition to viability, $\alpha$-synuclein secretion.

$\alpha$-Synuclein is exported in association with membrane vesicles that have the hallmarks of exosomes

We addressed the question of whether the nonclassical $\alpha$-synuclein secretion occurred via externalized membrane vesicles (Cooper and Barondes, 1990; Denzer et al., 2000; van Niel et al., 2006). Extracellular membrane vesicles were precipitated from the CM of $\alpha$-synuclein-expressing and nonexpressing CTL cells by centrifugation at 100,000 $\times g$. The supernatant (S100) and the pellet (P100) were analyzed by SDS-PAGE and immunoblotting for the presence of $\alpha$-synuclein. $\alpha$-Synuclein was readily detected in both the soluble and the membrane fraction of the $\mathrm{CM}$, suggesting that $\alpha$-synuclein is secreted, at least in part, in association with externalized membrane vesicles (Fig. $3 A$ ). Interestingly, oligomeric forms of $\alpha$-synuclein were also detected in the vesicle P100 fraction (supplemental Fig. S3A, available at www.jneurosci.org as supplemental material). To ensure that the presence of doxycycline itself or expression of $\alpha$-synuclein does not interfere with the generation of these externalized vesicles, we analyzed whole P100 pellets from the CM of $\alpha$-synuclein expressing ( - dox) and nonexpressing CTL ( + dox) 
cells by highly sensitive Coomasie blue staining and found that protein patterns were identical (supplemental Fig. S3B, available at www.jneurosci.org as supplemental material).

Recent studies have suggested that exosome-mediated export could play a critical role in the processing of proteins associated with neurodegenerative diseases, because $\beta$-amyloid (A $\beta$ ) peptides and prions were found to be externalized from cells via this pathway (Fevrier et al., 2004; Rajendran et al., 2006; Vella et al., 2008). To biochemically analyze the extracellular $\alpha$-synuclein-containing vesicles, the vesicular fraction (P100) from the $\mathrm{CM}$ of $\alpha$-synuclein-expressing and nonexpressing CTL cells was prepared and subjected to SDS-PAGE and immunoblotting. We found that $\mathrm{P} 100$ was positive for the exosome-specific proteins Alix and flotillin, as well as for Hsp70, GAPDH, and annexin II, proteins thought to be related with exosomes (Fevrier et al., 2004; Fauré et al., 2006; Rajendran et al., 2006; Théry et al., 2006; Trajkovic et al., 2008) (Fig. $3 B$ ). In addition, proteins reported to be excluded from exosomes, such as 143-3 $\beta$ and cofilin (Simpson et al., 2008), were both absent from P100 (Fig. 3B) (supplemental Fig. S3C, available at www. jneurosci.org as supplemental material). Unlike cofilin, which was shown to be absent from the $S 100$ fraction, $14-3-3 \beta$ was detected in the same fraction consistent with reports (Berg et al., 2003) showing the presence of 14-3-3 family members extracellularly (supplemental Fig. S3C, available at www.jneurosci.org as supplemental material). P100 also did not contain Rab5, a marker for early endosomes, or the transferrin receptor, a general marker for endosomal recycling (Fig. 3B).

To confirm that the CM of $\alpha$-synuclein-expressing cells contained exosomes, we isolated pure exosomes from the CM using a validated differential ultracentrifugation procedure (Théry et al., 2006). Western immunoblotting revealed that purified, Alix-positive, exosomes (P100) contained $\alpha$-synuclein (Fig. 3C). The morphological characteristics of $\alpha$-synuclein-positive vesicles were analyzed by electron microscopy. Electron micrographs of P100 revealed uniformly rounded, cap-shaped vesicles with diameters in the range of 50-140 nm (mean size, $89.1 \pm 2.3 \mathrm{~nm}$, mean \pm SEM; $n=77$ ), further arguing for the exosomal nature of these vesicles (Fig. 3D) (supplemental Fig. S3D, available at www. jneurosci.org as supplemental material). These results are in agreement with previous reports (Théry et al., 2002, 2006; Fauré et al., 2006; Vingtdeux et al., 2007; Yuyama et al., 2008). The protein composition of externalized exosomes was also analyzed using mass spectrometry. Proteomic analysis confirmed the presence of $\alpha$-synuclein in the exosome pellet of $\alpha$-synuclein-expressing cells (Fig. 3E). In agreement with previous studies (Wubbolts et al., 2003; Valadi et al., 2007; Simpson et al., 2008; Gonzalez-Begne et al., $t$ test, $\left.{ }^{*} p<0.01\right)$.

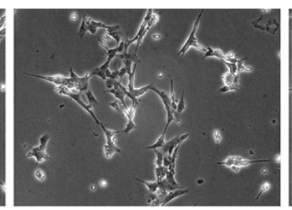

CM, bGAL-
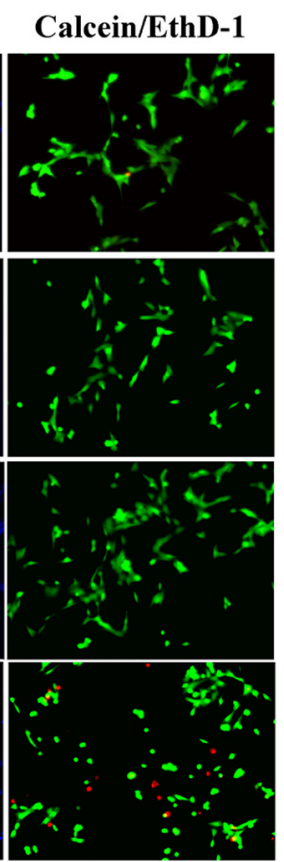

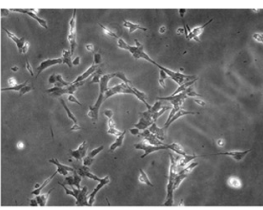

CM, WT+

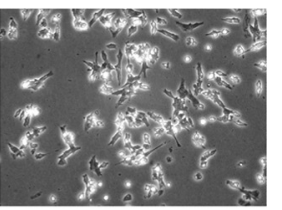

CM, WT-

C

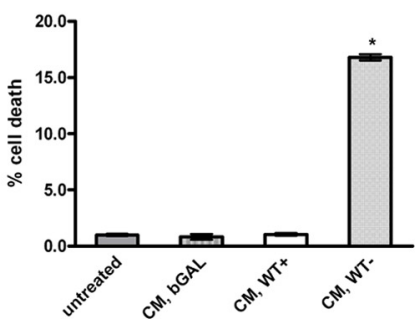

D

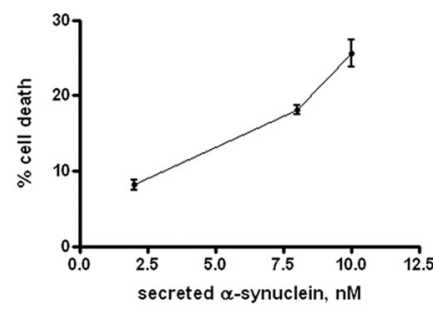

E

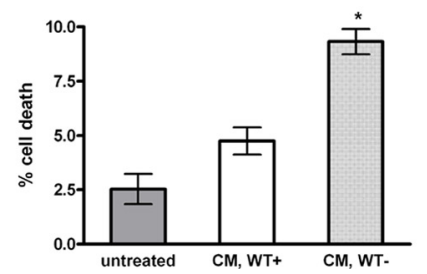

Figure 4. Secreted $\alpha$-synuclein induces cell death to differentiated SH-SY5Y cells. A, $\alpha$-Synuclein-expressing and uninduced CTL cells, as well as bGAL-expressing cells, were cultured in $2 \%$ FBS for $48 \mathrm{~h}$. CM was collected and applied to differentiated SH-SY5Y cells for $24 \mathrm{~h}$. Representative phase micrographs of the recipient cells are shown. Scale bar, $50 \mu \mathrm{m} . \boldsymbol{B}, \mathrm{CM}$ was prepared and used ( positive cells. Quantitative analysis demonstrated a statistically significant increase in cell death when recipient cells were treated with CM from $\alpha$-synuclein-expressing cells ( $n=4$; mean \pm SD, one-way ANOVA test followed by Tukey's test, ${ }^{*} p<0.001$ ). $\boldsymbol{D}$, CM was collected from $\alpha$-synuclein-expressing cells as in $\boldsymbol{A}$ and applied to differentiated SH-SY5Y cells for $24 \mathrm{~h}$. Cell death was 列 and Hoechst. Quantitative analysis showed a reduction in cell viability from $\alpha$-synuclein-rich CM $(n=4$; mean \pm SD, independent

2009), LC-MS proteomic analysis of our exosome preparation identified common, as well as cell-type-specific, proteins (supplemental table, available at www.jneurosci.org as supplemental material).

Together, these data demonstrate that $\alpha$-synuclein is exported via membrane vesicles that possess the characteristics of exosomes. To examine the topology of $\alpha$-synuclein found in the exosomes, we treated the P100 fraction with $\mathrm{Na}_{2} \mathrm{CO}_{3}$. Interestingly, $\alpha$-synuclein was present both in the membrane $(\mathrm{P})$ and the lumen $(\mathrm{S})$ of $\mathrm{Na}_{2} \mathrm{CO}_{3}$-treated exosomes (Fig. $3 \mathrm{~F}$ ).

\section{Medium from $\alpha$-synuclein-expressing cells is toxic to} differentiated SH-SY5Y cells and primary cortical neurons Recombinant $\alpha$-synuclein can cause cell death when added to recipient cells (Sung et al., 2001; Zhang et al., 2005; Ahn et al., 2006). We wanted to examine whether the physiologically secreted $\alpha$-synuclein from our cells could affect cell viability. 
A

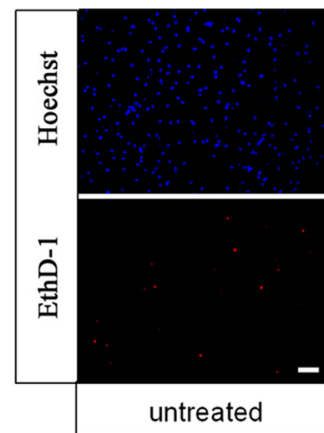

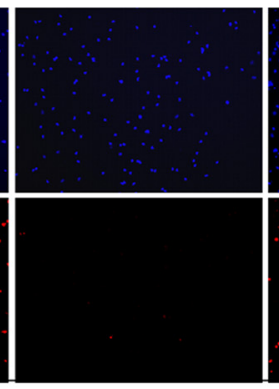

$\mathrm{CM}, \mathrm{WT}+$

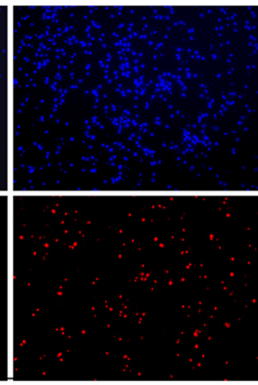

CM, WT-

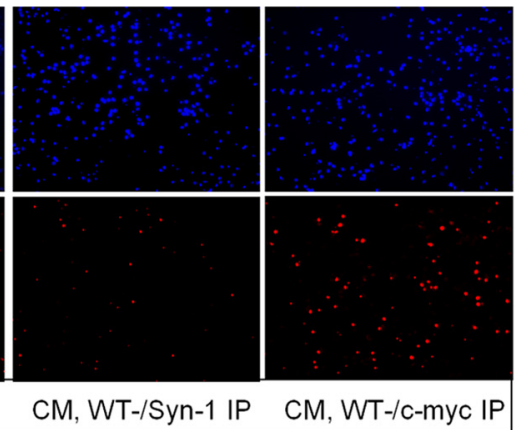

CM, WT-/Syn-1 IP CM, WT-/c-myc IP
B

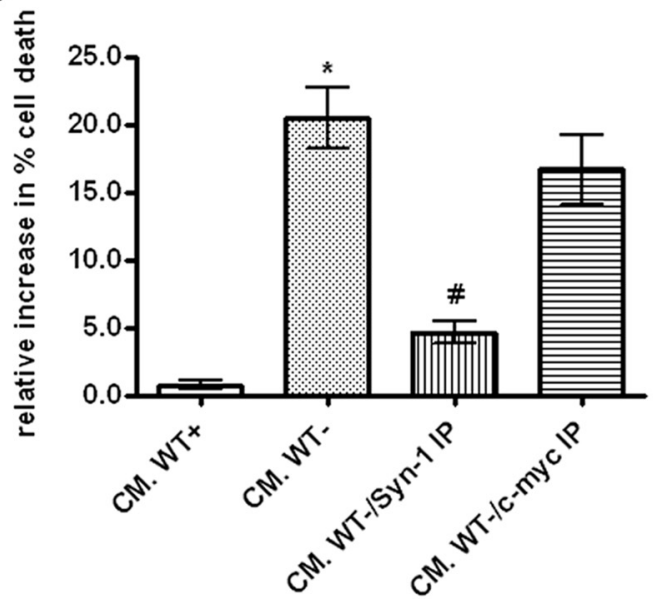

C

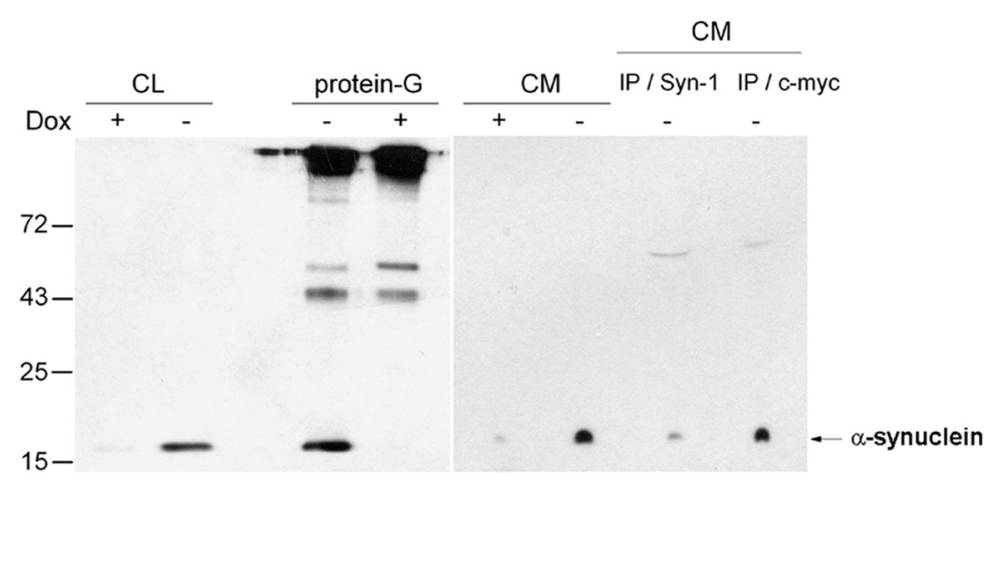

Figure 5. Immunodepletion of $\alpha$-synuclein from the CM reduces CM-induced toxicity. A, $\alpha$-Synuclein-expressing and nonexpressing CTL cells were cultured in $2 \%$ FBS for $48 \mathrm{~h}$. The CM was cleared from cell debris and immunoprecipitated with antibodies to $\alpha$-synuclein or c-myc. Immunodepleted and control CM were applied to rat embryonic cortical neurons for $24 \mathrm{~h}$. Recipient neurons were stained with EthD-1 (red) and Hoechst (blue). Scale bar, $10 \mu \mathrm{m}$. B, Quantification of the cell death revealed significant increases in cytotoxicity when $\alpha$-synuclein was present in the CM. Immunodepletion of $\alpha$-synuclein from the CM was protective against the death phenotype. Data are presented as mean $\pm S D(n=3)$ and analyzed with one-way ANOVA test followed by Tukey's test; ${ }^{*} p<0.001$ comparing CM from WT + with CM from WT-; ${ }^{*} p<0.001$ comparing CM from WT - with $\alpha$-synuclein-immunodepleted CM (WT-/Syn-1 IP). C, Cell lysates (CL) of $\alpha$-synuclein-expressing ( - dox) or nonexpressing (TL ( + dox) cells were immunoprecipitated and Western immunoblotted with the Syn- 1 antibody. $\alpha$-Synuclein was successfully immunoprecipitated. $\alpha$-Synuclein present in the CM of these cells was similarly immunoprecipitated. Under such conditions, the CM was almost completely depleted of $\alpha$-synuclein (CM/IP/Syn-1). As expected, control immunoprecipitation using the A-14 c-myc antibody (CM/IP/c-myc) had no effect on $\alpha$-synuclein levels.

$\alpha$-Synuclein-expressing and nonexpressing CTL cells, as well as bGAL-expressing cells, were cultured for $48 \mathrm{~h}$ in $2 \% \mathrm{FBS}$, and the CM was applied to differentiated SH-SY5Y cells for $24 \mathrm{~h}$. Application of the CM from $\alpha$-synuclein-expressing cells induced drastic morphological changes to recipient cells, characteristic of cellular degeneration such as process retraction and membrane blebbing (Fig. $4 A$ ). Cell death was determined to be $\sim 17 \%$ (percentage cell death, $16.8 \pm 0.6 \%$, mean $\pm \mathrm{SD} ; n=4)($ Fig. $4 B, C)$. Cells treated with CM from uninduced SH-SY5Y cells or bGALexpressing cells did not exhibit any abnormalities or cell death, suggesting that the observed cytotoxicity could be associated with the presence of $\alpha$-synuclein in the CM. Using recombinant $\alpha$-synuclein, we estimated the concentration of $\alpha$-synuclein in the CM. Interestingly, cell death correlated with the amount of secreted $\alpha$-synuclein present in the CM (Fig. 4D). Neuronal death was verified by assessment of caspase- 3 activation in the CM-treated differentiated SH-SY5Y cells. After treatment with CM, the recipient cells were lysed and analyzed by Western immunoblotting using an antibody against the cleaved caspase-3. Caspase-3 activation was only evident when cells were treated with CM containing secreted $\alpha$-synuclein (supplemental Fig. S4 A, available at www.jneurosci.org as supplemental material).

CM from $\alpha$-synuclein-expressing and nonexpressing CTL cells was also applied to cycling SH-SY5Y cells. Treatment of cycling cells with secreted $\alpha$-synuclein-containing CM for $24 \mathrm{~h}$ affected cell viability (percentage cell death, $9.3 \pm 1.2$ and $4.8 \pm$ $1.3 \%$ for CM from $\alpha$-synuclein-expressing and CTL cells, respectively, mean $\pm \mathrm{SD} ; n=4$ ) but to a lower extent compared with differentiated recipient sister cultures (Fig. $4 E$ ). Treatment of rat primary cortical neurons for $24 \mathrm{~h}$ with secreted $\alpha$-synuclein-rich $\mathrm{CM}$ resulted in a profound increase in neuronal degeneration, similar to that of differentiated SH-SY5Y cells (percentage cell death, $20.5 \pm 3.8 \%$, mean $\pm S D ; n=3$ ) (Fig. $5 A, B$ ). Importantly, effective immunodepletion of $\alpha$-synuclein from the CM using the $\alpha$-synuclein-specific antibody Syn-1 (Fig. 5C), before application on recipient neurons, significantly reduced neuronal loss (Fig. $5 A, B$ ), indicating that secreted $\alpha$-synuclein is, to a great extent, responsible for the observed neurotoxicity. Control immunodepletion using an irrelevant antibody did not rescue primary neurons from the secreted $\alpha$-synuclein-induced toxicity (Fig. $5 B$ ), further arguing that the death phenotype was attributable to the presence of $\alpha$-synuclein in the CM.

Extracellular $\alpha$-synuclein is internalized by proliferating SH-SY5Y cells but not differentiated SH-SY5Y cells or cortical neurons

It has been reported that recombinant $\alpha$-synuclein can be internalized by cells via endocytosis (Sung et al., 2001; Zhang et al., 
2005; Ahn et al., 2006). We used ${ }^{35}$ Slabeled $\mathrm{CM}$ as a source of secreted $\alpha$-synuclein to investigate whether cellproduced externalized $\alpha$-synuclein was uptaken by recipient proliferating cells. Labeled CM from bGAL-expressing cells was used as control. After ${ }^{35} \mathrm{~S}$ labeling of intracellular $\alpha$-synuclein (Fig. 6A, left), cells were grown in fresh medium for $16 \mathrm{~h}$, and the CM containing secreted labeled $\alpha$-synuclein was applied onto proliferating SH-SY5Y cells for $24 \mathrm{~h}$. After a $2 \mathrm{~min}$ treatment with trypsin-EDTA to remove nonspecific surface protein binding, cells were lysed and immunoprecipitated with Syn-1 antibody. Autoradiography demonstrated that labeled $\alpha$-synuclein could indeed be uptaken by recipient cycling cells (Fig. $6 A$, right). The uptake of extracellular $\alpha$-synuclein did not result in the formation of intracellular inclusions as was confirmed by negative Thioflavin S staining (data not shown). Interestingly, inhibition of the lysosomal pathway of recipient cells by $1 \mathrm{mM} \mathrm{NH}_{4} \mathrm{Cl}$ for $24 \mathrm{~h}$ exacerbated the toxicity of CM from $\alpha$-synuclein-expressing cells, suggesting that uptaken $\alpha$-synuclein may be degraded by the lysosome (supplemental Fig S $4 B$, available at www.jneurosci.org as supplemental material). Subcellular fractionation demonstrated the presence of labeled $\alpha$-synuclein in the microsomal fraction of the recipient cells (data not shown). To investigate whether neurons also uptake secreted $\alpha$-synuclein, we applied the CM containing labeled $\alpha$-synuclein to differentiated SH-SY5Y cells and rat cortical neurons. Unlike proliferating cells, cellproduced labeled $\alpha$-synuclein could not be detected inside neuronal cells even after prolonged film exposure (Fig. $6 \mathrm{~B}$ ). To rule out the possibility that the levels of internalized $\alpha$-synuclein were too low to be detected, we applied "cold" CM from $\alpha$-synuclein-expressing cells on rat cortical neuronal cultures for $16 \mathrm{~h}$ and checked for the presence of internalized human $\alpha$-synuclein. Lysates (600 $\mu \mathrm{g}$ ) were immunoprecipitated with the Syn-1 antibody and Western blotted with the human-specific LB 509 antibody. Internalization of human $\alpha$-synuclein was not evident even under these conditions (supplemental Fig.

$\mathrm{S} 4 C$, available at www.jneurosci.org as supplemental material). However, a very small amount of uptaken $\alpha$-synuclein could be detected in differentiated SH-SY5Y when trypsin-EDTA treatment was replaced by extensive (three times) washing with cold PBS (Fig. 6B).

It has been reported that recombinant $\alpha$-synuclein can activate microglia cells (Zhang et al., 2005; Su et al., 2008). To exam-

B
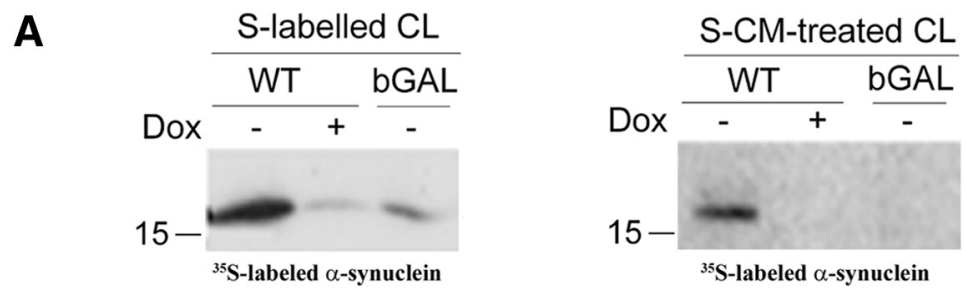

${ }^{35} \mathrm{~S}-\mathrm{CM}$-treated cells

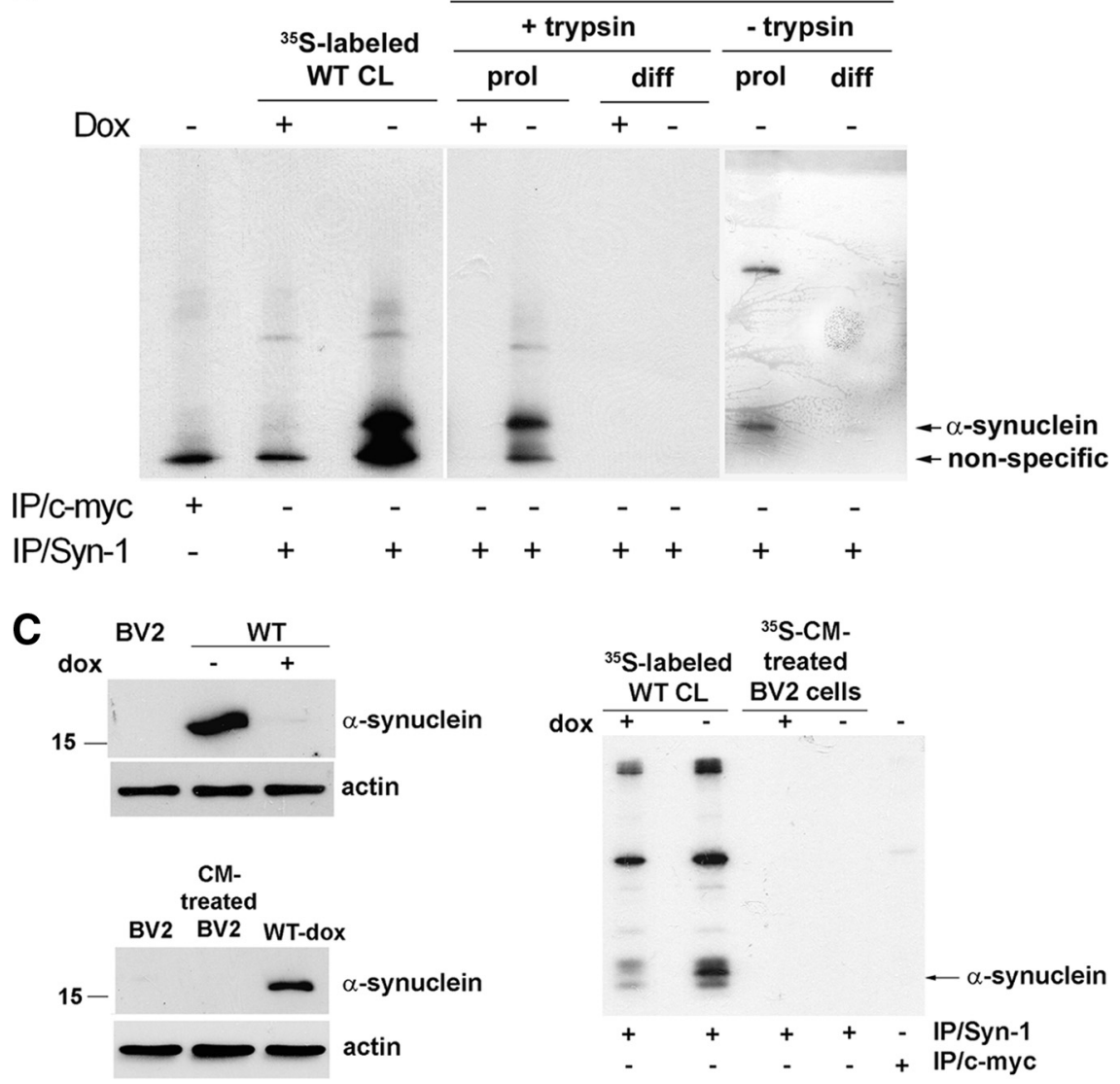

Figure 6. Externalized $\alpha$-synuclein is uptaken by proliferating SH-SY5Y cells but not neuronal cells. $\boldsymbol{A}, \alpha$-Synucleinexpressing ( - dox) or nonexpressing (TL ( + dox) cells and bGAL-expressing (bGAL-dox) cells were ${ }^{35}$ S labeled. CM from the labeled cells, containing labeled secreted proteins (see Materials and Methods), was applied to recipient cycling SH-SY5Y cells. Endogenously expressed (left) or uptaken (right) labeled $\alpha$-synuclein was detected in recipient cell extracts by gel autoradiography after immunoprecipitation of the cell lysates with Syn- 1 antibody. $\boldsymbol{B}$, As in $\boldsymbol{A}$, but c-myc immunoprecipitation was used as a negative control and CM from cells, containing abundant labeled secreted proteins, was applied to both recipient proliferating (prol) and differentiated (diff) SH-SY5Y cells. The recipient cells were either treated with trypsin-EDTA (+trypsin) or washed thoroughly (-trypsin). Gels were exposed for $30 \mathrm{~d}$. C, Left, BV2 cell lysate was analyzed for the presence of $\alpha$-synuclein by Syn- 1 immunoblotting compared with cells expressing ( - dox) or nonexpressing ( + dox) $\alpha$-synuclein. CM from $\alpha$-synuclein-expressing cells (WT-dox) was collected and applied to BV2 cells. Uptake of $\alpha$-synuclein by recipient BV2 cells was assessed in the cell lysates by Western immunoblotting using the Syn- 1 antibody. Actin was used as loading control. Right, $\alpha$-Synuclein-expressing ( - dox) or nonexpressing CTL ( + dox) cells were ${ }^{35} \mathrm{~S}$ labeled ( ${ }^{35}$ S-labeled WT CL). CM from the labeled cells was applied to recipient cycling BV2 cells, which were subsequently treated with trypsin-EDTA ( ${ }^{35} \mathrm{~S}$-CM-treated BV2 cells). Cell-produced (first and second lanes) or uptaken labeled $\alpha$-synuclein (third and fourth lanes) was detected in cell extracts by gel autoradiography after immunoprecipitation of the cell lysates with Syn-1 antibody. c-myc immunoprecipitation was used as a negative control (fifth lane).

ine whether naturally secreted $\alpha$-synuclein could be uptaken by microglia cells, murine BV2 microglia, which normally do not express $\alpha$-synuclein (Fig. 6C, left), were treated with CM rich in $\alpha$-synuclein or labeled $\alpha$-synuclein for 24 h. Uptaken $\alpha$-synuclein was assessed by immunoprecipitation and Western blotting. As depicted in Figure 6C, BV2 cells did not uptake extracellular $\alpha$-synuclein. 


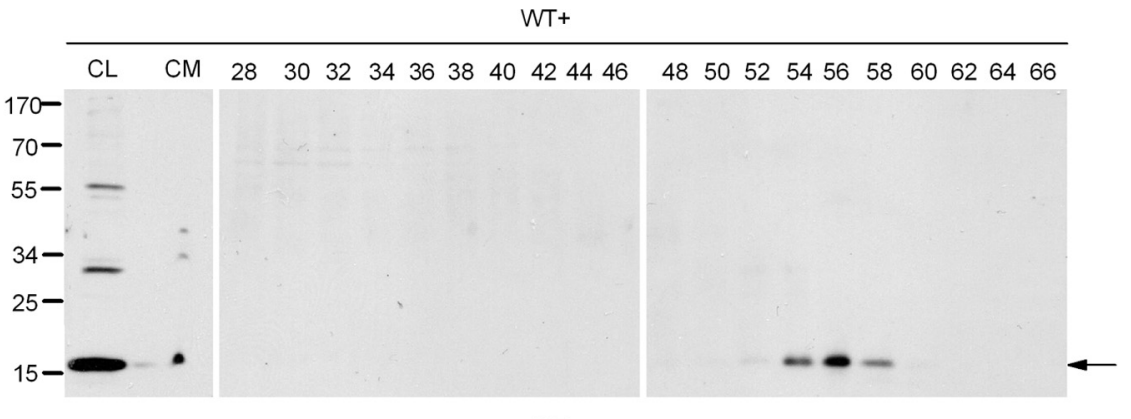

WT-

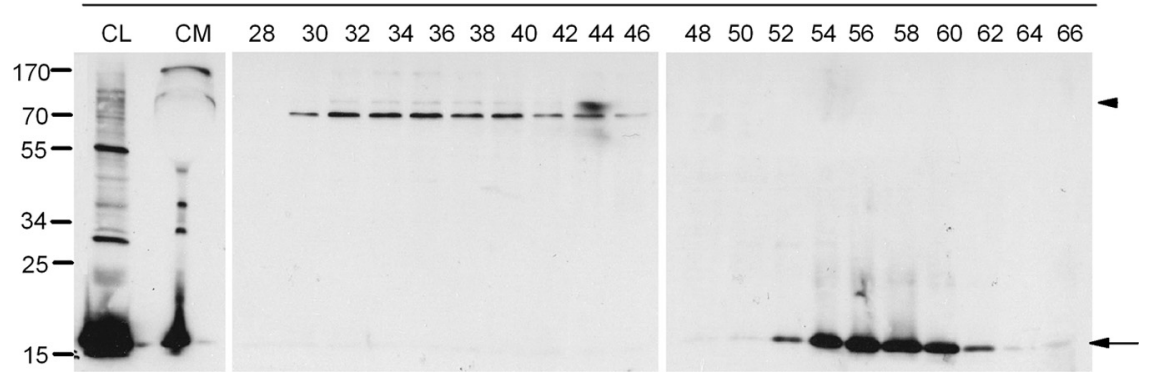

Figure 7. Extracellular $\alpha$-synuclein oligomeric and monomeric species are present in CM. $\alpha$-Synuclein-expressing (WT - ) and nonexpressing CTL (WT+) cells were cultured in 2\% FBS for $48 \mathrm{~h}$. The CM was cleared from cell debris, concentrated, and fractionated by SEC. The cell lysates (CL), the concentrated CM, and the SEC fractions corresponding to WT + and WT - cells were further analyzed for $\alpha$-synuclein with the Syn-1 antibody. Arrows show $\alpha$-synuclein present in LMW fractions, and arrowhead shows $\alpha$-synuclein present in HMW fractions.

A
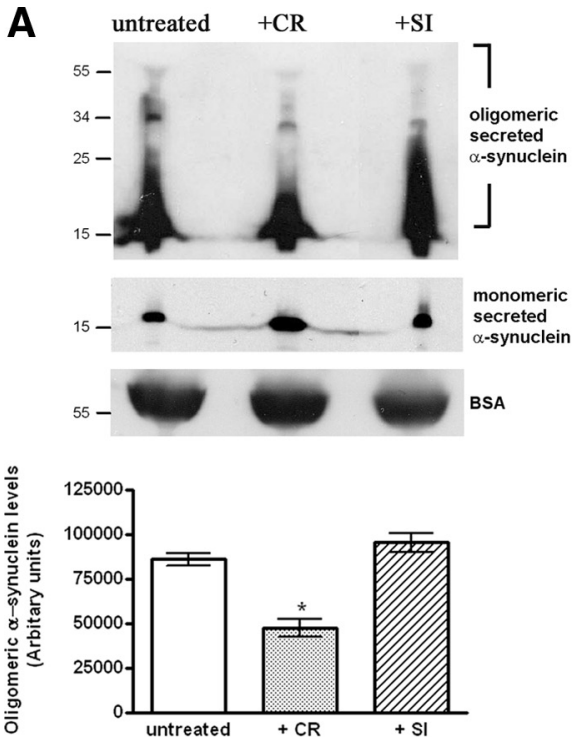

Figure 8. Treatment of secreted $\alpha$-synuclein-rich CM with oligomer-interfering compounds reduces CM-induced toxicity. $\boldsymbol{A}, \alpha$-Synuclein-expressing cells were cultured in $2 \% \mathrm{FBS}$ for $48 \mathrm{~h}$. The CM was cleared from cell debris and equal parts were treated with vehicle, $\mathrm{CR}(0.4 \mu \mathrm{M})$, or SI $(0.4 \mu \mathrm{m})$ for $4 \mathrm{~h}$ at $4^{\circ} \mathrm{C}$. CM was then concentrated and analyzed for $\alpha$-synuclein with the $\mathrm{C}-20$ antibody. After treatment, the levels of secreted $\alpha$-synuclein oligomers were quantified ( $n=3$; mean $\pm \mathrm{SD}$, one-way ANOVA test, $\left.{ }^{*} p<0.01\right)$. B, CM was collected and treated as in $\boldsymbol{A}$. After treatment with the compounds, CM was applied to differentiated SH-SY5Y cells for $24 \mathrm{~h}$. Survival was assayed by EthD-1/Hoechst staining. Data are shown as mean $\pm \mathrm{SD}(n=3)$. Statistical analysis was performed using the one-way ANOVA test followed by Tukey's test ( ${ }^{*} p<0.001$ comparing CM, WT + with CM, WT $-;{ }^{\#} p<0.001$ comparing CM, WT - with CM, WT - /CR or CM, WT - /SI).

\section{Both oligomeric and monomeric} $\boldsymbol{\alpha}$-synuclein species are found extracellularly

It has been reported that the presence of soluble oligomers of $\alpha$-synuclein may account for the pathogenic actions of $\alpha$-synuclein, although the mechanism through which this occurs remains unresolved (Vekrellis et al., 2004). Interestingly, $\alpha$-synu- clein oligomeric species were readily detected in the CM of $\alpha$-synucleinexpressing cells after concentration and immunoblotting with the polyclonal C-20 antibody (Figs. $1 B, 7$ ). These results were confirmed using the monoclonal Syn-1 antibody (data not shown). To provide additional evidence for the identity of these species, the concentrated CM from $\alpha$-synuclein-expressing and nonexpressing CTL cells was analyzed by SEC (supplemental Fig. S5A, available at www. jneurosci.org as supplemental material). SEC fractions were then subjected to SDSPAGE and immunoblotting for the presence of $\alpha$-synuclein using the C-20 antibody. Using this technique, HMW $(>580 \mathrm{kDa})$ and LMW (<38 kDa) $\alpha$-synuclein species, migrating under reducing conditions as (potentially) tetrameric and monomeric $\alpha$-synuclein, respectively, were effectively identified and separated (Fig. 7). Similar results were obtained with the Syn-1 antibody (data not shown).

\section{Treatment of CM with}

oligomer-interfering compounds partially rescues recipient cells from $\alpha$-synuclein-induced toxicity

To investigate whether extracellular $\alpha$-synuclein oligomers are critical for the observed secreted $\alpha$-synuclein-induced cytotoxicity, we treated the CM with two oligomer-interfering compounds, CR and SI. CR has been shown to effectively disrupt preformed oligomeric/aggregated forms of various proteins, including mutant $\alpha$-synuclein or Huntingtin (Carter and Chou, 1998; Sánchez et al., 2003; Emmanouilidou et al., 2010). SI, a cellpermeable sugar, can successfully neutralize the adverse effects of $\mathrm{A} \beta$ oligomeric species, possibly by stabilizing a nontoxic conformation of $\mathrm{A} \beta$ oligomers (McLaurin et al., 2000; Townsend et al., 2006). CM from $\alpha$-synuclein-expressing cells and nonexpressing CTL cells was treated with $0.4 \mu \mathrm{M} \mathrm{CR}$ or SI for $4 \mathrm{~h}$ at $4^{\circ} \mathrm{C}$. SDS-PAGE and immunoblotting analysis of such CM after concentration revealed that, consistent with previous findings, treatment of the CM with CR caused an obvious reduction of extracellular $\alpha$-synuclein oligomeric species and a simultaneous increase of monomeric $\alpha$-synuclein, possibly attributable to the collapse of oligomers to monomers (Fig. 8A). No change in the levels of the $\alpha$-synuclein oligomers was observed after SI treatment of the CM (Fig. $8 A$ ). In addition, CR or SI treatments did not affect the membrane integrity of exosomes present in the CM (supplemental Fig. S5B, available at www.jneurosci.org as supplemental material). When CR- or SItreated CM was applied to differentiated SH-SY5Y cells for $4 \mathrm{~h}$, this 
resulted in a significant, $\sim 50 \%$, reduction of toxicity from secreted $\alpha$-synuclein (Fig. $8 B$ ). When CM was treated with chiroinositol (CI), an inactive isomer of SI, there was no promotion of survival of the recipient cells (Fig. $8 \mathrm{~B}$ ), indicating that the rescue effect of SI was indeed related with its anti-oligomeric action. These data suggest that naturally secreted $\alpha$-synuclein oligomers are, at least in part, responsible for the $\alpha$-synucleininduced cytotoxity in recipient cells.

SEC fractions containing either HMW or LMW secreted $\boldsymbol{\alpha}$-synuclein species reduce the viability of differentiated SH-SY5Y cells

Our data using CR and SI supported the notion that $\alpha$-synuclein oligomers could be involved in secreted $\alpha$-synucleininduced toxicity. Because we detected several distinct $\alpha$-synuclein species in the CM (Fig. 7), we wanted to examine whether the toxicity observed could be attributed to particular $\alpha$-synuclein species. For this purpose, $\alpha$-synuclein-expressing and nonexpressing CTL cells were cultured in 2\% FBS for $48 \mathrm{~h}$, and the CM was concentrated and analyzed by SEC. HMW and LMW fractions containing $\alpha$-synuclein were pooled, buffer exchanged, and lyophilized. After their reconstitution in growth medium, HMW and LMW fractions were applied separately on differentiated SH-SY5Y cells for $48 \mathrm{~h}$. Interestingly, both HMW and LMW fractions induced cell degeneration to recipient cells (Fig. 9A) almost to the same extent (percentage cell death, $8.9 \pm 0.5$ and $11.8 \pm 1.6 \%$ for HMW and LMW fractions, respectively, mean $\pm \mathrm{SD} ; n=3$ ) (Fig. 9B).

\section{Discussion}

Because of the lack of an ER signaling peptide from its sequence, $\alpha$-synuclein was considered to be exclusively localized and exert its pathogenic effects intracellularly. However, there is emerging evidence suggesting that $\alpha$-synuclein can be secreted in the extracellular space, thereby affecting the homeostasis of neighboring neurons possibly by a neuron-to-neuron transmission mechanism (Lee, 2008; Desplats et al., 2009). In the current study, using an inducible WT $\alpha$-synuclein SH-SY5Y cell line, we investigated the mechanism of $\alpha$-synuclein secretion and the effects of this secretion in the homeostasis of recipient neurons. Importantly, the levels of secreted $\alpha$-synuclein (2-12 nM) in our cell system were similar to those reported in biological fluids (Borghi et al., 2000; El-Agnaf et al., 2003). Our data strongly support that $\alpha$-synuclein is physiologically secreted in the extracellular space in association with membrane vesicles. The protein composition, morphology, and size of these vesicles were found to be similar to exosomes, small (40-100 nm), endosome-derived vesicles secreted by a multitude of cell types during fusion of multivesicular bodies with the plasma membrane. In support of this idea, impairment of the endocytic pathway by weak bases resulted in a profound increase in $\alpha$-synuclein secretion. Exosome-mediated exocytosis is a calcium-dependent process (Raposo et al., 1997; Savina et al., 2003, 2005). By using $\mathrm{Ca}^{2+}$ ionophores/chelators, we have found that $\alpha$-synuclein secretion is greatly affected by changes in intracellular, but not extracellular, calcium concentration. However, we cannot exclude the possibility that alternative mechanisms for $\alpha$-synuclein secretion, such as secretory vesiclemediated exocytosis, may also operate in our cell system. Indeed, part of intracellular $\alpha$-synuclein was found previously to be localized in secretory vesicles (Lee et al., 2005).

Exosomes are considered to be biologically active entities that can interact with recipient cells in a variety of ways, such as endocytosis, receptor-ligand binding, attachment, or fusion with the plasma membrane (Théry et al., 2002; Vincent and Magee, 2002; Keller et al., 2006; van Niel et al., 2006). Alternatively, extracellular degradation of the exosomal membrane by proteases or lipases could allow the release of proteins from the exosomal lumen to the extracellular matrix (Mehul and Hughes, 1997; Hughes, 1999). Initially, the release of exosomes was considered to be a cellular mechanism of clearing unnecessary proteins (Pan et al., 1985; Johnstone et al., 1987; van Niel et al., 2006; Vella et al., 2008). The novel finding that $\alpha$-synuclein can be exported from the cell via the exosomal pathway provides a common pathway for the delivery of a potentially toxic protein in the extracellular space, thereby spreading its pathogenic actions in neighboring healthy cells. Interestingly, exosomes bearing prions were efficient initiators of prion propagation in uninfected recipient cells and produced prion disease when inoculated into mice (Fevrier et al., 2004; Vella et al., 2007, 2008). $\beta$-Amyloid peptides of intracellular origin were found to be released in association with exosomes (Rajendran et al., 2006). Moreover, cultured cortical neurons can secrete exosomes (Fauré et al., 2006). In this context, our data support the Trojan Horse hypothesis in which neurodegeneration results from the progressive propagation of pathogenic events, cell by cell, throughout brain areas (Caughey, 2000; Ghidoni et al., 2008; Lee, 2008). The finding that grafted healthy neurons can gradually develop $\alpha$-synuclein pathology as host neurons many years after transplantation provides additional support for a prion-like mechanism for the spread of PD 
(Brundin et al., 2008). However, it remains unclear whether internalization of released $\alpha$-synuclein or some other factor is responsible for the development of $\alpha$-synuclein deposits in the transplanted cells.

We show that CM containing soluble secreted $\alpha$-synuclein can cause cell death to healthy recipient cells that is associated with caspase- 3 activation. Degeneration was greatly amplified when the recipient cells have a neuronal phenotype, such as differentiated SH-SY5Y cells or primary cortical neurons. The cell death was associated with secreted $\alpha$-synuclein because immunodepletion of $\alpha$-synuclein from the CM significantly ameliorated the cytotoxic effects. Importantly, death correlated with extracellular $\alpha$-synuclein concentration.

CM from WT-expressing SH-SY5Y cells was found to contain soluble monomeric and oligomeric $\alpha$-synuclein. We isolated HMW and LMW secreted $\alpha$-synuclein species and evaluated their toxicity. Both species decreased the viability of recipient differentiated neuroblastoma cells. Our data indicate that presence of either cell-derived HMW or LMW $\alpha$-synuclein species extracellularly can decrease cell viability, suggesting that high $n$-oligomeric or low $n$-monomeric $\alpha$-synuclein could act in a synergistic way to trigger neurodegeneration. Importantly, the molar amount of HMW $\alpha$-synuclein was much lower than that of LMW $\alpha$-synuclein, suggesting that, on a molar basis, HMW oligomeric $\alpha$-synuclein exerted greater cytotoxicity.

Further supporting a critical role for the extracellular $\alpha$-synuclein oligomers, treatment of the CM with oligomer-interfering compounds, such as CR and SI, partially rescued the recipient cells from $\alpha$-synuclein-induced toxicity. In a number of studies, CR has been used to disrupt $\beta$-sheet-rich species, including $\alpha$-synuclein, huntingtin, and A $\beta$ (Heiser et al., 2000; Sánchez et al., 2003; Inouye and Kirschner, 2005). Indeed, CR dissociated the $\alpha$-synuclein oligomeric species contained in the CM. Although CR did not affect the integrity of the exosomes in the CM, we cannot exclude the possibility that CR may also act by preventing the interaction of exosomes with the plasma membrane. The mechanism by which SI interacts with $\beta$-sheet conformations is not known. In our hands, SI did not disrupt the extracellular $\alpha$-synuclein oligomeric species, nor did it affect exosomal integrity. This is consistent with our previous finding that SI does not disrupt intracellular $\alpha$-synuclein oligomeric species despite its survival-promoting effects (Vekrellis et al., 2009). It has been hypothesized that SI could stabilize a nontoxic oligomeric conformation preventing the production of the more toxic protofibrils (McLaurin et al., 2000; Townsend et al., 2006).

Critical to the understanding of the toxic effects of secreted $\alpha$-synuclein is the issue of whether it is internalized by recipient cells. In our hands, secreted $\alpha$-synuclein appears to be readily uptaken by cycling SH-SY5Y cells but not to any significant degree by neuronal cells or microglia. This difference may point to cell-type-specific mechanisms of uptake. This may be especially applicable to oligomeric species, which, because of their low abundance, cannot be detected by autoradiography in our hands. Recent evidence suggests that $\alpha$-synuclein uptake by neuronal cells depends highly on its fibrilarization state. Furthermore, cationic liposomes have been shown to be necessary for the delivery of fibrillar recombinant $\alpha$-synuclein inside neuronal cells (Luk et al., 2009). Because we can only detect soluble but not fibrilar $\alpha$-synuclein species in the medium of our cells, it is possible that these do not efficiently enter recipient neurons. Lee et al. (2008) have also suggested that aggregated $\alpha$-synuclein is internalized more efficiently, and via a different pathway, compared with the monomeric protein. However, caution is needed in the interpre- tation of these results, because they are based on very high amounts of the recombinant protein.

Although we cannot exclude the possibility that secreted $\alpha$-synuclein exerts its toxic effects by uptake into recipient cells, in which it could impact cellular homeostasis in various ways, for example via disruption of protein degradation pathways (Sánchez et al., 2003; Inouye and Kirschner, 2005), the fact that these effects are more pronounced in neuronal cells in which limited uptake is detected raises the possibility that they are mediated extracellularly at the level of cell membrane. It is tempting to speculate that extracellular secreted $\alpha$-synuclein could trigger degeneration via a specific signaling process. This process could be initiated by an interaction of secreted $\alpha$-synuclein with the plasma membrane, possibly through a specialized, so far unidentified, receptor. Alternatively, and according to the amyloid pore model, the interaction of secreted $\alpha$-synuclein with cellular membranes could result in pore formation, which greatly compromises membrane integrity, and lead to neuronal degeneration via the creation of significant alterations in the equilibrium of ions and small metabolites between the cytoplasm and the extracellular space (Heiser et al., 2000; Volles et al., 2001; Volles and Lansbury, 2003). In support of this idea, in a number of studies pre-formed $\alpha$-synuclein protofibrils generated from recombinant $\alpha$-synuclein have been shown to cause neurotoxicity when added to the culture medium of healthy cells (El-Agnaf et al., 1998; Du et al., 2003; Zhang et al., 2005).

In conclusion, we demonstrate here that $\alpha$-synuclein is secreted from neuronal cells in a calcium-dependent manner by exosomes and that, at physiological concentrations, it can impact the viability of neighboringneurons. Oligomericsecreted $\alpha$-synuclein species are in part responsible for these effects. These findings provide an understanding of the mechanism of spread of pathology in PD and offer the opportunity to modulate this process at either the level of secretion of $\alpha$-synuclein or the level of its impact on neighboring cells.

\section{References}

Ahn KJ, Paik SR, Chung KC, Kim J (2006) Amino acid sequence motifs and mechanistic features of the membrane translocation of alpha-synuclein. J Neurochem 97:265-279.

Albani D, Peverelli E, Rametta R, Batelli S, Veschini L, Negro A, Forloni G (2004) Protective effect of TAT-delivered alpha-synuclein: relevance of the C-terminal domain and involvement of HSP70. FASEB J 18:1713-1715.

Andrei C, Dazzi C, Lotti L, Torrisi MR, Chimini G, Rubartelli A (1999) The secretory route of the leaderless protein interleukin lbeta involves exocytosis of endolysosome-related vesicles. Mol Biol Cell 10:1463-1475.

Barclay JW, Morgan A, Burgoyne RD (2005) Calcium-dependent regulation of exocytosis. Cell Calcium 38:343-353.

Berg D, Holzmann C, Riess O (2003) 14-3-3 proteins in the nervous system. Nat Rev Neurosci 4:752-762.

Borghi R, Marchese R, Negro A, Marinelli L, Forloni G, Zaccheo D, Abbruzzese G, Tabaton M (2000) Full length alpha-synuclein is present in cerebrospinal fluid from Parkinson's disease and normal subjects. Neurosci Lett 287:65-67.

Brundin P, Li JY, Holton JL, Lindvall O, Revesz T (2008) Research in motion: the enigma of Parkinson's disease pathology spread. Nat Rev Neurosci 9:741-745.

Carter DB, Chou KC (1998) A model for structure-dependent binding of Congo red to Alzheimer beta-amyloid fibrils. Neurobiol Aging 19:37-40.

Caughey B (2000) Transmissible spongiform encephalopathies, amyloidoses and yeast prions: common threads? Nat Med 6:751-754.

Chang HC, Samaniego F, Nair BC, Buonaguro L, Ensoli B (1997) HIV-1 Tat protein exits from cells via a leaderless secretory pathway and binds to extracellular matrix-associated heparan sulfate proteoglycans through its basic region. AIDS 11:1421-1431.

Chartier-Harlin MC, Kachergus J, Roumier C, Mouroux V, Douay X, Lincoln 
S, Levecque C, Larvor L, Andrieux J, Hulihan M, Waucquier N, Defebvre L, Amouyel P, Farrer M, Destée A (2004) Alpha-synuclein locus duplication as a cause of familial Parkinson's disease. Lancet 364:1167-1169.

Conway KA, Lee SJ, Rochet JC, Ding TT, Williamson RE, Lansbury PT Jr (2000) Acceleration of oligomerization, not fibrillization, is a shared property of both alpha-synuclein mutations linked to early-onset Parkinson's disease: implications for pathogenesis and therapy. Proc Natl Acad Sci U S A 97:571-576.

Conway KA, Rochet JC, Bieganski RM, Lansbury PT Jr (2001) Kinetic stabilization of the alpha-synuclein protofibril by a dopamine-alphasynuclein adduct. Science 294:1346-1349.

Cooper DN, Barondes SH (1990) Evidence for export of a muscle lectin from cytosol to extracellular matrix and for a novel secretory mechanism. J Cell Biol 110:1681-1691.

Denzer K, Kleijmeer MJ, Heijnen HF, Stoorvogel W, Geuze HJ (2000) Exosome: from internal vesicle of the multivesicular body to intercellular signaling device. J Cell Sci 113:3365-3374.

Desplats P, Lee HJ, Bae EJ, Patrick C, Rockenstein E, Crews L, Spencer B, Masliah E, Lee SJ (2009) Inclusion formation and neuronal cell death through neuron-to-neuron transmission of alpha-synuclein. Proc Natl Acad Sci U S A 106:13010-13015.

Du HN, Tang L, Luo XY, Li HT, Hu J, Zhou JW, Hu HY (2003) A peptide motif consisting of glycine, alanine, and valine is required for the fibrillization and cytotoxicity of human alpha-synuclein. Biochemistry 42:8870-8878.

El-Agnaf OM, Jakes R, Curran MD, Middleton D, Ingenito R, Bianchi E, Pessi A, Neill D, Wallace A (1998) Aggregates from mutant and wild-type alpha-synuclein proteins and NAC peptide induce apoptotic cell death in human neuroblastoma cells by formation of beta-sheet and amyloid-like filaments. FEBS Lett 440:71-75.

El-AgnafOM, Salem SA, Paleologou KE, Cooper LJ, Fullwood NJ, Gibson MJ, Curran MD, Court JA, Mann DM, Ikeda S, Cookson MR, Hardy J, Allsop D (2003) Alpha-synuclein implicated in Parkinson's disease is present in extracellular biological fluids, including human plasma. FASEB J 17:1945-1947.

El-Agnaf OM, Salem SA, Paleologou KE, Curran MD, Gibson MJ, Court JA, Schlossmacher MG, Allsop D (2006) Detection of oligomeric forms of alpha-synuclein protein in human plasma as a potential biomarker for Parkinson's disease. FASEB J 20:419-425.

Emmanouilidou E, Stefanis L, Vekrellis K (2010) Cell-produced alphasynuclein oligomers are targeted to, and impair, the $26 \mathrm{~S}$ proteasome. Neurobiol Aging 31:953-968.

Fauré J, Lachenal G, Court M, Hirrlinger J, Chatellard-Causse C, Blot B, Grange J, Schoehn G, Goldberg Y, Boyer V, Kirchhoff F, Raposo G, Garin J, Sadoul R (2006) Exosomes are released by cultured cortical neurones. Mol Cell Neurosci 31:642-648.

Fevrier B, Vilette D, Archer F, Loew D, Faigle W, Vidal M, Laude H, Raposo G (2004) Cells release prions in association with exosomes. Proc Natl Acad Sci U S A 101:9683-9688.

Fujiki Y, Hubbard AL, Fowler S, Lazarow PB (1982) Isolation of intracellular membranes by means of sodium carbonate treatment: application to endoplasmic reticulum. J Cell Biol 93:97-102.

Geetha T, Wooten MW (2008) TrkA receptor endolysosomal degradation is both ubiquitin and proteasome dependent. Traffic 9:1146-1156.

Ghidoni R, Benussi L, Binetti G (2008) Exosomes: the Trojan horses of neurodegeneration. Med Hypotheses 70:1226-1227.

Goldberg MS, Lansbury PT Jr (2000) Is there a cause-and-effect relationship between alpha-synuclein fibrillization and Parkinson's disease? Nat Cell Biol 2:E115-E119.

Gonzalez-Begne M, Lu B, Han X, Hagen FK, Hand AR, Melvin JE, Yates JR (2009) Proteomic analysis of human parotid gland exosomes by multidimensional protein identification technology (MudPIT). J Proteome Res 8:1304-1314.

Heiser V, Scherzinger E, Boeddrich A, Nordhoff E, Lurz R, Schugardt N, Lehrach H, Wanker EE (2000) Inhibition of huntingtin fibrillogenesis by specific antibodies and small molecules: implications for Huntington's disease therapy. Proc Natl Acad Sci U S A 97:6739-6744.

Hughes RC (1999) Secretion of the galectin family of mammalian carbohydrate-binding proteins. Biochim Biophys Acta 1473:172-185.

Ibáñez P, Bonnet AM, Débarges B, Lohmann E, Tison F, Pollak P, Agid Y, Dürr A, Brice A (2004) Causal relation between alpha-synuclein gene duplication and familial Parkinson's disease. Lancet 364:1169-1171.
Inouye H, Kirschner DA (2005) Alzheimer's beta-amyloid: insights into fibril formation and structure from Congo red binding. Subcell Biochem 38:203-224.

Jackson A, Friedman S, Zhan X, Engleka KA, Forough R, Maciag T (1992) Heat shock induces the release of fibroblast growth factor 1 from NIH 3T3 cells. Proc Natl Acad Sci U S A 89:10691-10695.

Johnstone RM, Adam M, Hammond JR, Orr L, Turbide C (1987) Vesicle formation during reticulocyte maturation. Association of plasma membrane activities with released vesicles (exosomes). J Biol Chem 262: 9412-9420.

Keller S, Sanderson MP, Stoeck A, Altevogt P (2006) Exosomes: from biogenesis and secretion to biological function. Immunol Lett 107:102-108.

Klinkspoor JH, Tytgat GN, Lee SP, Groen AK (1996) Mechanism of bile salt-induced mucin secretion by cultured dog gallbladder epithelial cells. Biochem J 316:873-877.

Kouri ED, Labrou NE, Garbis SD, Kalliampakou KI, Stedel C, Dimou M, Udvardi MK, Katinakis P, Flemetakis E (2009) Molecular and biochemical characterization of the parvulin-type PPIases in Lotus japonicus. Plant Physiol 150:1160-1173.

Lanzetti L (2007) Actin in membrane trafficking. Curr Opin Cell Biol 19:453-458.

Lee HJ, Patel S, Lee SJ (2005) Intravesicular localization and exocytosis of alpha-synuclein and its aggregates. J Neurosci 25:6016-6024.

Lee HJ, Suk JE, Bae EJ, Lee JH, Paik SR, Lee SJ (2008) Assembly-dependent endocytosis and clearance of extracellular alpha-synuclein. Int J Biochem Cell Biol 40:1835-1849.

Lee SJ (2008) Origins and effects of extracellular alpha-synuclein: implications in Parkinson's disease. J Mol Neurosci 34:17-22.

Lindstedt R, Apodaca G, Barondes SH, Mostov KE, Leffler H (1993) Apical secretion of a cytosolic protein by Madin-Darby canine kidney cells. Evidence for polarized release of an endogenous lectin by a nonclassical secretory pathway. J Biol Chem 268:11750-11757.

Luk KC, Song C, O'Brien P, Stieber A, Branch JR, Brunden KR, Trojanowski JQ, Lee VM (2009) Exogenous $\alpha$-synuclein fibrils seed the formation of Lewy body-like intracellular inclusions in cultured cells. Proc Natl Acad Sci U S A 106:20051-20056.

McLaurin J, Golomb R, Jurewicz A, Antel JP, Fraser PE (2000) Inositol stereoisomers stabilize an oligomeric aggregate of Alzheimer amyloid beta peptide and inhibit A $\beta$-induced toxicity. J Biol Chem 275:18495-18502.

Mehul B, Hughes RC (1997) Plasma membrane targetting, vesicular budding and release of galectin 3 from the cytoplasm of mammalian cells during secretion. J Cell Sci 110:1169-1178.

Melchior F, Gerace L (1995) Mechanisms of nuclear protein import. Curr Opin Cell Biol 7:310-318.

Mills IG, Urbé S, Clague MJ (2001) Relationships between EEA1 binding partners and their role in endosome fusion. J Cell Sci 114:1959-1965.

Olanow CW, Perl DP, DeMartino GN, McNaught KS (2004) Lewy-body formation is an aggresome-related process: a hypothesis. Lancet Neurol 3:496-503.

Pan BT, Teng K, Wu C, Adam M, Johnstone RM (1985) Electron microscopic evidence for externalization of the transferrin receptor in vesicular form in sheep reticulocytes. J Cell Biol 101:942-948.

Poole B, Ohkuma S (1981) Effect of weak bases on the intralysosomal pH in mouse peritoneal macrophages. J Cell Biol 90:665-669.

Rajendran L, Honsho M, Zahn TR, Keller P, Geiger KD, Verkade P, Simons K (2006) Alzheimer's disease beta-amyloid peptides are released in association with exosomes. Proc Natl Acad Sci U S A 103:11172-11177.

Raposo G, Tenza D, Mecheri S, Peronet R, Bonnerot C, Desaymard C (1997) Accumulation of major histocompatibility complex class II molecules in mast cell secretory granules and their release upon degranulation. Mol Biol Cell 8:2631-2645.

Rideout HJ, Larsen KE, Sulzer D, Stefanis L (2001) Proteasomal inhibition leads to formation of ubiquitin/alpha-synuclein-immunoreactive inclusions in PC12 cells. J Neurochem 78:899-908.

Rubartelli A, Cozzolino F, Talio M, Sitia R (1990) A novel secretory pathway for interleukin-1 beta, a protein lacking a signal sequence. EMBO J 9:1503-1510.

Sánchez I, Mahlke C, Yuan J (2003) Pivotal role of oligomerization in expanded polyglutamine neurodegenerative disorders. Nature 421:373379.

Saraste J, Palade GE, Farquhar MG (1986) Temperature-sensitive steps in 
the transport of secretory proteins through the Golgi complex in exocrine pancreatic cells. Proc Natl Acad Sci U S A 83:6425-6429.

Savina A, Furlán M, Vidal M, Colombo MI (2003) Exosome release is regulated by a calcium-dependent mechanism in K562 cells. J Biol Chem 278:20083-20090.

Savina A, Fader CM, Damiani MT, Colombo MI (2005) Rab11 promotes docking and fusion of multivesicular bodies in a calcium-dependent manner. Traffic 6:131-143.

Seino S, Shibasaki T (2005) PKA-dependent and PKA-independent pathways for cAMP-regulated exocytosis. Physiol Rev 85:1303-1342.

Sherer TB, Betarbet R, Stout AK, Lund S, Baptista M, Panov AV, Cookson MR, Greenamyre JT (2002) An in vitro model of Parkinson's disease: linking mitochondrial impairment to altered $\alpha$-synuclein metabolism and oxidative damage. J Neurosci 22:7006-7015.

Simpson RJ, Jensen SS, Lim JW (2008) Proteomic profiling of exosomes: current perspectives. Proteomics 8:4083-4099.

Singleton AB, Farrer M, Johnson J, Singleton A, Hague S, Kachergus J, Hulihan M, Peuralinna T, Dutra A, Nussbaum R, Lincoln S, Crawley A, Hanson M, Maraganore D, Adler C, Cookson MR, Muenter M, Baptista M, Miller D, Blancato J, Hardy J, Gwinn-Hardy K (2003) alpha-Synuclein locus triplication causes Parkinson's disease. Science 302:841.

Smolian H, Aurer A, Sittinger M, Zacher J, Bernimoulin JP, Burmester GR, Kolkenbrock H (2001) Secretion of gelatinases and activation of gelatinase A (MMP-2) by human rheumatoid synovial fibroblasts. Biol Chem 382:1491-1499.

Su X, Maguire-Zeiss KA, Giuliano R, Prifti L, Venkatesh K, Federoff HJ (2008) Synuclein activates microglia in a model of Parkinson's disease. Neurobiol Aging 29:1690-1701.

Sung JY, Kim J, Paik SR, Park JH, Ahn YS, Chung KC (2001) Induction of neuronal cell death by Rab5A-dependent endocytosis of alpha-synuclein. J Biol Chem 276:27441-27448.

Sung JY, Park SM, Lee CH, Um JW, Lee HJ, Kim J, Oh YJ, Lee ST, Paik SR, Chung KC (2005) Proteolytic cleavage of extracellular secreted \{alpha\}synuclein via matrix metalloproteinases. J Biol Chem 280:25216-25224.

Tanudji M, Hevi S, Chuck SL (2002) Improperly folded green fluorescent protein is secreted via a non-classical pathway. J Cell Sci 115:3849-3857.

Thastrup O, Cullen PJ, Drøbak BK, Hanley MR, Dawson AP (1990) Thapsigargin, a tumor promoter, discharges intracellular $\mathrm{Ca} 2+$ stores by specific inhibition of the endoplasmic reticulum $\mathrm{Ca}^{2+}$-ATPase. Proc Natl Acad Sci U S A 87:2466-2470.

Théry C, Zitvogel L, Amigorena S (2002) Exosomes: composition, biogenesis and function. Nat Rev Immunol 2:569-579.

Théry C, Amigorena S, Raposo G, Clayton A (2006) Isolation and characterization of exosomes from cell culture supernatants and biological fluids. Curr Protoc Cell Biol Chapter 3:Unit 3.22.

Townsend M, Cleary JP, Mehta T, Hofmeister J, Lesne S, O'Hare E, Walsh DM, Selkoe DJ (2006) Orally available compound prevents deficits in memory caused by the Alzheimer amyloid-beta oligomers. Ann Neurol 60:668-676.
Trajkovic K, Hsu C, Chiantia S, Rajendran L, Wenzel D, Wieland F, Schwille P, Brügger B, Simons M (2008) Ceramide triggers budding of exosome vesicles into multivesicular endosomes. Science 319:1244-1247.

Valadi H, Ekström K, Bossios A, Sjöstrand M, Lee JJ, Lötvall JO (2007) Exosome-mediated transfer of mRNAs and microRNAs is a novel mechanism of genetic exchange between cells. Nat Cell Biol 9:654-659.

van Niel G, Porto-Carreiro I, Simoes S, Raposo G (2006) Exosomes: a common pathway for a specialized function. J Biochem 140:13-21.

Vekrellis K, Rideout HJ, Stefanis L (2004) Neurobiology of alpha-synuclein. Mol Neurobiol 30:1-21.

Vekrellis K, Xilouri M, Emmanouilidou E, Stefanis L (2009) Inducible overexpression of wild type alpha-synuclein in human neuronal cells leads to caspase-dependent non-apoptotic death. J Neurochem 109:1348-1362.

Vella LJ, Sharples RA, Lawson VA, Masters CL, Cappai R, Hill AF (2007) Packaging of prions into exosomes is associated with a novel pathway of PrP processing. J Pathol 211:582-590.

Vella LJ, Sharples RA, Nisbet RM, Cappai R, Hill AF (2008) The role of exosomes in the processing of proteins associated with neurodegenerative diseases. Eur Biophys J 37:323-332.

Vincent JP, Magee T (2002) Argosomes: membrane fragments on the run. Trends Cell Biol 12:57-60.

Vingtdeux V, Hamdane M, Loyens A, Gelé P, Drobeck H, Bégard S, Galas MC, Delacourte A, Beauvillain JC, Buée L, Sergeant N (2007) Alkalizing drugs induce accumulation of amyloid precursor protein by-products in luminal vesicles of multivesicular bodies. J Biol Chem 282:18197-18205.

Vogiatzi T, Xilouri M, Vekrellis K, Stefanis L (2008) Wild type alphasynuclein is degraded by chaperone-mediated autophagy and macroautophagy in neuronal cells. J Biol Chem 283:23542-23556.

Volles MJ, Lansbury PT Jr (2003) Zeroing in on the pathogenic form of alpha-synuclein and its mechanism of neurotoxicity in Parkinson's disease. Biochemistry 42:7871-7878.

Volles MJ, Lee SJ, Rochet JC, Shtilerman MD, Ding TT, Kessler JC, Lansbury PT Jr (2001) Vesicle permeabilization by protofibrillar alpha-synuclein: implications for the pathogenesis and treatment of Parkinson's disease. Biochemistry 40:7812-7819.

Wubbolts R, Leckie RS, Veenhuizen PT, Schwarzmann G, Möbius W, Hoernschemeyer J, Slot JW, Geuze HJ, Stoorvogel W (2003) Proteomic and biochemical analyses of human B cell-derived exosomes. Potential implications for their function and multivesicular body formation. J Biol Chem 278:10963-10972.

Yuyama K, Yamamoto N, Yanagisawa K (2008) Accelerated release of exosome-associated GM1 ganglioside (GM1) by endocytic pathway abnormality: another putative pathway for GM1-induced amyloid fibril formation. J Neurochem 105:217-224.

Zhang W, Wang T, Pei Z, Miller DS, Wu X, Block ML, Wilson B, Zhang W, Zhou Y, Hong JS, Zhang J (2005) Aggregated alpha-synuclein activates microglia: a process leading to disease progression in Parkinson's disease. FASEB J 19:533-542. 